\title{
Synthesis and Structural Characterization of Complexes of a DO3A-Conjugated Triphenylphosphonium Cation with Diagnostically Important Metal lons
}

\author{
Chang-Tong Yang ${ }^{1}$, Yongxin $\mathrm{Li}^{2}$, and Shuang Liu ${ }^{1},{ }^{*}$ \\ 1 School of Health Sciences, Purdue University, West Lafayette, Indiana, USA \\ 2 School of Physical and Mathematical Sciences, Nanyang Technological University, Singapore
}

\section{Abstract}

To understand the coordination chemistry of a DO3A-conjugated triphenylphosphonium (TPP) cation, triphenyl(4-((4,7,10-tris(carboxymethyl)-1,4,7,10-tetraazacyclododecan-1-yl)methyl) benzyl)phosphonium (DO3A-xy-TPP), with diagnostically important metal ions, In(DO3A-xyTPP $)^{+}, \mathrm{Ga}(\mathrm{DO} 3 \mathrm{~A}-\mathrm{xy}-\mathrm{TPP})^{+}$and $\mathrm{Mn}$ (DO3A-xy-TPP) were prepared by reacting DO3A-xy-TPP with one equivalent of the respective metal salt. All three complexes have been characterized by elemental analysis, IR, ESI-MS, NMR methods for In(DO3A-xy-TPP) ${ }^{+}$and Ga(DO3A-xy-TPP) ${ }^{+}$, and X-ray crystallography. Results from HPLC concordance experiments show that ${ }^{111} \operatorname{In}(\mathrm{DO} 3 \mathrm{~A}-\mathrm{xy}-\mathrm{TPP})^{+}$and In(DO3A-xy-TPP) $)^{+}$have the same composition. The solid state structures of In(DO3A-xy-TPP) ${ }^{+}$ and $\mathrm{Mn}(\mathrm{DO} 3 \mathrm{~A}-\mathrm{xy}-\mathrm{TPP})$ are very similar with DO3A being heptadentate in bonding to In(III) and $\mathrm{Mn}(\mathrm{II})$ in a monocapped octahedral coordination geometry. Because of the smaller size of $\mathrm{Ga}(\mathrm{III})$, the DO3A in $\mathrm{Ga}(\mathrm{DO} 3 \mathrm{~A}-\mathrm{xy}-\mathrm{TPP})^{+}$is only hexadentate with four amine- $\mathrm{N}$ and two carboxylate-O atoms bonding to $\mathrm{Ga}(\mathrm{III})$. One carboxylic acid group in DO3A is deprotonated to in order balance the positive charge of $\mathrm{Ga}(\mathrm{III})$. The coordination geometry of $\mathrm{Ga}(\mathrm{DO} 3 \mathrm{~A}-\mathrm{xy}-\mathrm{TPP})^{+}$is best described as a distorted octahedron. The NMR data shows that the coordinated DO3A in $\operatorname{In}(\mathrm{DO} 3 \mathrm{~A}-\mathrm{xy}-$ $\mathrm{TPP})^{+}$and $\mathrm{Ga}(\mathrm{DO} 3 \mathrm{~A}-\mathrm{xy}-\mathrm{TPP})^{+}$is symmetrical in aqueous solution. There is no dissociation of the acetate chelating arms in $\mathrm{In}(\mathrm{DO} 3 \mathrm{~A}-\mathrm{xy}-\mathrm{TPP})^{+}$and $\mathrm{Ga}(\mathrm{DO} 3 \mathrm{~A}-\mathrm{xy}-\mathrm{TPP})^{+}$, providing indirect evidence for the high solution stability of ${ }^{111} \mathrm{In}(\mathrm{DO} 3 \mathrm{~A}-\mathrm{xy}-\mathrm{TPP}){ }^{+}$and ${ }^{68} \mathrm{Ga}(\mathrm{DO} 3 \mathrm{~A}-\mathrm{xy}-\mathrm{TPP})^{+}$.

\section{INTRODUCTION}

Alteration in the electric component or mitochondrial membrane potential $\left(\Delta \Psi_{\mathrm{m}}\right)$ is an important characteristic of cancer caused directly by mitochondrial dysfunction, such as DNA mutation and oxidative stress. ${ }^{1-4}$ It has been reported that the mitochondrial transmembrane potential in carcinoma cells is significantly higher than that in normal epithelial cells. ${ }^{5-9}$ For example, the difference in $\Delta \Psi_{\mathrm{m}}$ between the CX-1 colon carcinoma cells and the control green monkey kidney epithelial cell line was approximately $60 \mathrm{mV}(163 \mathrm{mV}$ in tumor cells vs. 104 $\mathrm{mV}$ in normal cells). The observation that the enhanced mitochondrial transmembrane potential is prevalent in tumor cell phenotype provides the conceptual basis for development of mitochondrial targeting diagnostic and therapeutic pharmaceuticals. ${ }^{1-3,10-13}$

Measurement of mitochondrial transmembrane potential $\left(\Delta \Psi_{\mathrm{m}}\right)$ provides the most comprehensive reflection of mitochondrial bio-energetic function primarily because it depends

* To whom correspondence should be addressed. School of Health Sciences, Purdue University, 550 Stadium Mall Drive, West Lafayette, IN 47907. Phone: 765-494-0236; Fax 765-496-1377; Email: lius@ pharmacy.purdue.edu. 
directly on the proper integration of diverse metabolic pathways that converge at mitochondria. Since the plasma and mitochondrial transmembrane potentials are negative, delocalized cationic molecules with appropriate structural features are driven electrophoretically through these membranes and tend to accumulate inside the energized mitochondria. ${ }^{1-4,11}$ For example, lipophilic cations, such as rhodamine-123 and ${ }^{3} \mathrm{H}$-tetraphenylphosphonium $\left({ }^{3} \mathrm{H}\right.$ TPP), have been widely used to measure mitochondrial potentials in tumor cells. ${ }^{1,14-16}$ According to the Nernst equation, the $60 \mathrm{mV}$ difference in $\Delta \Psi_{\mathrm{m}}$ between carcinoma and control epithelial cell is theoretically sufficient to account for a 10 -fold greater accumulation of cationic compounds in carcinoma mitochondria than in normal cells. ${ }^{1-4,11}$ In addition, the plasma membrane potential $(30-90 \mathrm{mV})$ also pre-concentrates cationic species relative to the external medium, thus affecting the cytoplasmic concentration of these compounds and their availability for mitochondrial uptake.

Recently, several groups reported the use of radiolabeled triphenylphosphonium (TPP) cations, such as $4-\left({ }^{18} \mathrm{~F}-b e n z y l\right)$ triphenylphosphonium (Figure 1: ${ }^{18} \mathrm{~F}$-BzTPP), as positron emission tomography (PET) potential radiotracers for tumor and heart imaging. ${ }^{17-25}$ Even though ${ }^{3} \mathrm{H}-$ tetraphenylphosphonium (Figure 1: ${ }^{3} \mathrm{H}-\mathrm{TPP}$ ) was reported to have a better tumor uptake than ${ }^{99 \mathrm{~m}} \mathrm{Tc}$-Sestamibi, its tumor selectivity is very poor with the tumor/heart ratio being $<0.2 .19,{ }^{23}$ In addition, ${ }^{3} \mathrm{H}$-TPP is not suitable for imaging purposes. The high uptake of ${ }^{18} \mathrm{~F}$ BzTPP in the heart and liver may also impose a significant challenge for its clinical applications in diagnosis of cancer in the chest and abdominal regions. Thus, there is an urgent need for new radiotracers that have high tumor-selectivity, and are able to provide information of mitochondrial bio-energetic function in tumors by monitoring mitochondrial potential in a noninvasive fashion.

Previously, we reported several ${ }^{64} \mathrm{Cu}$-labeled triphenylphosphonium (TPP) cations, such as ${ }^{64} \mathrm{Cu}$ (DO3A-xy-TPP) (Figure 1: DO3A-xy-TPP = triphenyl(4-((4,7,10-tris

(carboxymethyl)-1,4,7,10-tetraazacyclododecan-1-yl)methyl)benzyl)phosphonium), as new radiotracers for imaging tumor by positron emission tomography (PET). ${ }^{26}$ The TPP moiety acts as the "mitochondrion-targeting biomolecule" to carry ${ }^{64} \mathrm{Cu}$ into tumor cells. ${ }^{26} \mathrm{DO} 3 \mathrm{~A}$ is used as the bifunctional chelator since it is able to form highly stable radiometal chelates with radionuclides, such as ${ }^{64} \mathrm{Cu}$ and ${ }^{68} \mathrm{Ga}$ for PET, ${ }^{111} \mathrm{In}$ for single photon emission computed tomography (SPECT), ${ }^{90} \mathrm{Y}$ and ${ }^{177} \mathrm{Lu}$ for radiotherapy. Biodistribution and microPET imaging studies have demonstrated that the ${ }^{64} \mathrm{Cu}$-labeled TPP cations are able to localize in tumors with high tumor uptake $(2-3.5 \% \mathrm{ID} / \mathrm{g})$ and high tumor selectivity (tumor/heart ratio $\approx 5: 1$ at $2 \mathrm{~h}$ postinjection as compared to tumor/heart ratio being $<0.2$ during the $2 \mathrm{~h}$ study period for ${ }^{99 \mathrm{~m}} \mathrm{Tc}$-Sestamibi). The high tumor selectivity of the ${ }^{64} \mathrm{Cu}$-labeled TPP cations is related to their low lipophilicity. ${ }^{26}$ The in vitro assay data show that ${ }^{64} \mathrm{Cu}$ (DO3A-xy-TPP) is able to localize in mitochondria of U87MG glioma cells. The ${ }^{111}$ In-labeled TPP cations also have high tumor uptake; but their tumor selectivity is not as good as that of their ${ }^{64} \mathrm{Cu}$ analogs. ${ }^{27}$

In our previous report, ${ }^{26}$ we described the synthesis of $\mathrm{Cu}$ (DO3A-xy-TPP) as part of the characterization of ${ }^{64} \mathrm{Cu}$-labeled TPP cations. However, we were not able to obtain crystals of $\mathrm{Cu}$ (DO3A-xy-TPP) suitable for structural determination by X-ray crystallography. In order to understand the coordination chemistry of DO3A-conjugated TPP cations with diagnostically important metals and the impact of radiometal chelates on biological properties of the radiolabeled TPP cations, we prepared In(III), Ga(III) and $\mathrm{Mn}$ (II) complexes of DO3A-xyTPP. We are interested in Ga(III) and In(III) complexes because of their potential applications as PET $\left({ }^{68} \mathrm{Ga}\right)$ and SPECT $\left({ }^{67} \mathrm{Ga}\right.$ and $\left.{ }^{111} \mathrm{In}\right)$ radiotracers. The $\mathrm{Mn}(\mathrm{II})$ complex is of our particular interest for its potential as a magnetic resonance imaging (MRI) contrast agent and its similarity to that of its $\mathrm{Cu}$ (II) analog with respect to molecular charge. In this report, we present the synthesis and structural characterization of $\mathrm{M}(\mathrm{DO} 3 \mathrm{~A}-\mathrm{xy}-\mathrm{TPP})^{+}(\mathrm{M}=\mathrm{Ga}$ and $\mathrm{In})$ and $\mathrm{Mn}(\mathrm{DO} 3 \mathrm{~A}-\mathrm{xy}-\mathrm{TPP})$. The main objective of this study is to determine their structures in 
both solid state and solution. Biodistribution and imaging data for ${ }^{64} \mathrm{Cu}$-labeled TPP cations has been described previously. ${ }^{26}$ Biological evaluation for the ${ }^{111}$ In-labeled TPP cations will be reported as a separate account. ${ }^{27}$

\section{EXPERIMENTAL SECTION}

\section{Materials and Instruments}

Chemicals were obtained from Sigma/Aldrich (St. Louis). 1,4,7,10-

Tetraazacyclododecane-4,7,10-tris $\left(t\right.$-butyl acetate) $\left(\mathrm{DO} 3 \mathrm{~A}(\mathrm{OBu}-\mathrm{t})_{3}\right)$ was purchased from Macrocyclics Inc. (Dallas, TX). NMR $\left({ }^{1} \mathrm{H},{ }^{13} \mathrm{C},{ }^{31} \mathrm{P},{ }^{1} \mathrm{H}-{ }^{1} \mathrm{H}\right.$ COSY, HMQC, HSQC, HMBC, NOESY) data were obtained using a Bruker DRX $300 \mathrm{MHz}$ and a Bruker Avance $500 \mathrm{MHz}$ FT NMR spectrometer. Chemical shifts are reported in ppm relative to TMS. Infrared (IR) spectra were recorded on a Perkin Elmer FT-IR spectrometer. Mass spectra were collected using positive mode on a Finnigan LCQ classic mass spectrometer, School of Pharmacy, Purdue University. Elemental analysis was performed by Dr. H. Daniel Lee using a PerkinElmer Series III analyser, Department of Chemistry, Purdue University.

\section{HPLC Method}

The HPLC method used equipped with a UV/vis detector $(\lambda=254 \mathrm{~nm})$, a $\beta$-ram IN-US detector and a Zorbax Rx-C18 column $(4.6 \mathrm{~mm} \times 150 \mathrm{~mm}, 300 \AA$ pore size $)$. The flow rate was $1 \mathrm{~mL} /$ min with the mobile phase being isocratic with $80 \%$ solvent A (10 mM ammonium acetate) and $20 \%$ solvent B (acetonitrile) at $0-5 \mathrm{~min}$, followed by a gradient mobile phase going from $20 \% \mathrm{~B}$ at $5 \mathrm{~min}$ to $60 \% \mathrm{~B}$ at $20 \mathrm{~min}$.

\section{$\ln ($ DO3A-xy-TPP)(OAC)}

DO3A-xy-TPP was prepared according to the procedure described in our previous report. ${ }^{26}$ DO3A-xy-TPP $(71.1 \mathrm{mg}, 0.1 \mathrm{mmol})$ and $\mathrm{In}(\mathrm{OAc})_{3}(29.1 \mathrm{mg}, 0.1 \mathrm{mmol})$ were dissolved in 0.2 $\mathrm{mL} \mathrm{NH} \mathrm{N}_{4} \mathrm{OAc}$ buffer $(0.5 \mathrm{M}, \mathrm{pH}=6.0)$. The mixture was stirred and heated at $100{ }^{\circ} \mathrm{C}$ for 30 $\mathrm{min}$. After filtration, the filtrate was transferred into a clean $5 \mathrm{~mL}$ vial. Slow diffusion of acetone into the reaction mixture produced colorless crystals suitable for X-ray crystallography. The solid was separated by filtration and dried under vacuum overnight before being submitted for elemental analysis. The yield was $52.2 \mathrm{mg}(\sim 63.5 \%)$. A sample was analyzed by HPLC. The HPLC retention time was 14.7 min with the purity $>95 \%$. IR ( $\mathrm{cm}^{-1}, \mathrm{KBr}$ pellet): 1629.6 (s, $\left.v_{\mathrm{C}=\mathrm{O}}\right)$ and $3435.2\left(\mathrm{bs}, \mathrm{v}_{\mathrm{O}-\mathrm{H}}\right)$. ESI-MS: $\mathrm{m} / z=823.16$ for $[\mathrm{M}+\mathrm{H}]^{+}(823.60 \mathrm{calcd}$. for $\left.\left[\mathrm{C}_{40} \mathrm{H}_{45} \mathrm{InN}_{4} \mathrm{O}_{6} \mathrm{P}\right]^{+}\right)$. The ${ }^{1} \mathrm{H}$ and ${ }^{13} \mathrm{C}$ NMR data are listed in Table $1 .{ }^{31} \mathrm{P} \mathrm{NMR}\left(\mathrm{D}_{2} \mathrm{O}, 500 \mathrm{~Hz}\right.$, $\left.25^{\circ} \mathrm{C}\right): 19.5$ (s, 1P). Anal. Calcd. for $\mathrm{C}_{42} \mathrm{H}_{48} \mathrm{InN}_{4} \mathrm{O}_{8} \mathrm{P} \cdot\left(\mathrm{CH}_{3}\right)_{2} \mathrm{CO} \cdot 3 \mathrm{H}_{2} \mathrm{O}: \mathrm{C}, 54.32 ; \mathrm{H}, 6.03 ; \mathrm{N}$, 5.63. Found: C, 54.68; H, 6.19; N, 5.76.

\section{$\mathrm{Ga}(\mathrm{DO} 3 \mathrm{~A}-\mathrm{xy}-\mathrm{TPP})\left(\mathrm{NO}_{3}\right)$}

$\mathrm{Ga}$ (DO3A-xy-TPP) $\left(\mathrm{NO}_{3}\right)$ was prepared using $\mathrm{Ga}\left(\mathrm{NO}_{3}\right)_{3} \mathrm{H} \cdot{ }_{2} \mathrm{O}(27.3 \mathrm{mg}, 0.1 \mathrm{mmol})$ according to the same procedure for In(DO3A-xy-TPP)(OAc). Slow diffusion of acetone into the reaction mixture produced colorless crystals suitable for X-ray crystallography. The solid was separated and dried under vacuum overnight before being submitted for elemental analysis. The yield was $64.4 \mathrm{mg}(\sim 67.6 \%)$. The HPLC retention time was $14.8 \mathrm{~min}$ with the purity $>95 \%$. IR $\left(\mathrm{cm}^{-1}, \mathrm{KBr}\right.$ pellet): $1632.7\left(\mathrm{~s}, v_{\mathrm{C}=\mathrm{O}}\right), 1726.6\left(\mathrm{~s}, v_{\mathrm{C}=\mathrm{O}}\right)$ and $3441.3\left(\mathrm{bs}, v_{\mathrm{O}-\mathrm{H}}\right)$. ESI-MS: $\mathrm{m} / z=$ 777.02 for $[\mathrm{M}+\mathrm{H}]^{+}\left(778.50\right.$ calcd. for $\left.\left[\mathrm{C}_{40} \mathrm{H}_{45} \mathrm{GaN}_{4} \mathrm{O}_{6} \mathrm{P}\right]^{+}\right) .{ }^{1} \mathrm{H}$ and ${ }^{13} \mathrm{C}$ NMR data are listed in Table 1. ${ }^{31} \mathrm{P}$ NMR $\left(\mathrm{D}_{2} \mathrm{O}, 300 \mathrm{~Hz}, 25^{\circ} \mathrm{C}\right): 26.3$ (s, 1P). Anal. Calcd. For $\mathrm{C}_{40} \mathrm{H}_{46} \mathrm{GaN}_{5} \mathrm{O}_{9}$. $\left(\mathrm{CH}_{3}\right)_{2} \mathrm{CO} \cdot 3 \mathrm{H}_{2} \mathrm{O}: \mathrm{C}, 54.16 ; \mathrm{H}, 6.06 ; \mathrm{N}, 7.35$. Found: $\mathrm{C}, 54.42 ; \mathrm{H}, 5.93 ; \mathrm{N}, 7.02$.

Mn(DO3A-xy-TPP)—Mn(DO3A-xy-TPP) was prepared using $\mathrm{MnCl}_{2}(12.5 \mathrm{mg}, 0.1 \mathrm{mmol})$ according to the same procedure for $\operatorname{In}(\mathrm{DO} 3 \mathrm{~A}-\mathrm{xy}-\mathrm{TPP})(\mathrm{OAc})$. Slow diffusion of methanol into 
the reaction mixture afforded colorless crystals suitable for X-ray crystallography. The solid was separated and dried under vacuum before being submitted for elemental analysis. The yield was $61.7 \mathrm{mg}(\sim 71.2 \%)$. A sample was analyzed by HPLC. The retention time was $16.8 \mathrm{~min}$ with the purity $>95 \%$. IR $\left(\mathrm{cm}^{-1}, \mathrm{KBr}\right.$ pellet): $1637.1\left(\mathrm{~s}, v_{\mathrm{C}=\mathrm{O}}\right)$ and $3429.3\left(\mathrm{bs}, v_{\mathrm{O}-\mathrm{H}}\right)$. ESI-MS: $m / z=764.09$ for $[\mathrm{M}+\mathrm{H}]^{+}\left(763.72\right.$ calcd. for $\left.\left[\mathrm{C}_{40} \mathrm{H}_{45} \mathrm{MnN}_{4} \mathrm{O}_{6} \mathrm{P}\right]\right)$. Anal. Calcd. for $\mathrm{C}_{40} \mathrm{H}_{45} \mathrm{MnN}_{4} \mathrm{O}_{6} \mathrm{P} \cdot 4 \mathrm{H}_{2} \mathrm{O} \cdot \mathrm{CH}_{3} \mathrm{OH}: \mathrm{C}, 54.46 ; \mathrm{H}, 7.03 ; \mathrm{N}, 5.72$. Found: C, 54.24; H, 6.71; N, 5.70 .

\section{${ }^{111} \operatorname{In}(\mathrm{DO} 3 \mathrm{~A}-\mathrm{xy}-\mathrm{TPP})^{+}$}

To a clean $3 \mathrm{~mL}$ plastic vial were added $0.5 \mathrm{~mL} \mathrm{NH}_{4} \mathrm{OAc}$ buffer $(0.1 \mathrm{M}, \mathrm{pH}=6.9)$ containing $50 \mu \mathrm{g}$ of the DO3A-xy-TPP and $0.10 \mathrm{~mL}$ of ${ }^{111} \mathrm{InCl}_{3}$ solution $(0.2-2.0 \mathrm{mCi})$ in $0.05 \mathrm{~N} \mathrm{HCl}$.

The mixture was heated at $100{ }^{\circ} \mathrm{C}$ for $30 \mathrm{~min}$. After cooling to room temperature, a sample of the resulting solution was analyzed by radio-HPLC. The HPLC retention time was $14.7 \mathrm{~min}$. The HPLC concordance experiment was performed by injecting the HPLC-purified ${ }^{111}$ In $(\mathrm{DO} 3 \mathrm{~A}-\mathrm{xy}-\mathrm{TPP})^{+}$and $\operatorname{In}(\mathrm{DO} 3 \mathrm{~A}-\mathrm{xy}-\mathrm{TPP})^{+}$sequentially under the same chromatographic conditions.

\section{X-ray Crystallographic Analysis}

Crystallographic data for In(DO3A-xy-TPP $)(\mathrm{OAc}) \cdot 7.5 \mathrm{H}_{2} \mathrm{O} \cdot\left(\mathrm{CH}_{3}\right)_{2} \mathrm{CO}, \mathrm{Ga}(\mathrm{DO} 3 \mathrm{~A}-\mathrm{xy}-\mathrm{TPP})$ $\left(\mathrm{NO}_{3}\right) \cdot 6 \mathrm{H}_{2} \mathrm{O} \cdot\left(\mathrm{CH}_{3}\right)_{2} \mathrm{CO}$ and $\mathrm{Mn}(\mathrm{DO} 3 \mathrm{~A}-\mathrm{xy}-\mathrm{TPP}) \cdot 4 \mathrm{H}_{2} \mathrm{O} \cdot \mathrm{CH}_{3} \mathrm{OH}$ were collected on a Nonius Kappa CCD diffractometer, and are listed in Table 2. Crystals were mounted on a glass fiber in a random orientation. Preliminary examination and data collection were performed using graphite monochromated Mo $\mathrm{K}_{\alpha}$ radiation $(\lambda=0.71073 \AA)$. Cell constants for data collection were obtained from least-squares refinement, using the setting angles of 23636 reflections in the range $2<\lambda<25^{\circ}$ for $\operatorname{In}(\mathrm{DO} 3 \mathrm{~A}-\mathrm{xy}-\mathrm{TPP})(\mathrm{OAc}) \cdot 7.5 \mathrm{H}_{2} \mathrm{O} \cdot\left(\mathrm{CH}_{3}\right)_{2} \mathrm{CO}$. A total of 23636 reflections were collected and 9031 reflections were unique. Lorentz and polarization corrections were applied to the data. The linear absorption coefficient is $5.6 \mathrm{~cm}^{-1}$ for Mo $\mathrm{K}_{\alpha}$ radiation. An empirical absorption correction using SCALEPACK ${ }^{28}$ was applied. The structure was solved by direct methods using Charge Flipping 29 in PLUTON ${ }^{30}$. There are eight oxygen atom positions of water molecules found in $\operatorname{In}(\mathrm{DO} 3 \mathrm{~A}-\mathrm{xy}-\mathrm{TPP})(\mathrm{OAc}) \cdot 7.5 \mathrm{H}_{2} \mathrm{O}$. $\left(\mathrm{CH}_{3}\right)_{2} \mathrm{CO}$, seven of which have full occupancies while one has fractional occupancy. For $\mathrm{Ga}$ (DO3A-xy-TPP) $\left(\mathrm{NO}_{3}\right) \cdot 6 \mathrm{H}_{2} \mathrm{O} \cdot\left(\mathrm{CH}_{3}\right)_{2} \mathrm{CO}$, cell constants for data collection were obtained from least-squares refinement, using the setting angles of 18858 reflections in the range $3<\lambda<$ $27^{\circ}$. The refined mosaicity from DENZO/SCALEPACK ${ }^{28}$ was $0.34^{\circ}$ indicating good crystal quality. A total of 18858 reflections were collected, of which 8697 were unique. Frames were integrated with DENZO-SMN. ${ }^{28}$ Lorentz and polarization corrections were applied to the data. The linear absorption coefficient is $7.0 \mathrm{~cm}^{-1}$ for Mo $\mathrm{K}_{\mathrm{a}}$ radiation. An empirical absorption correction using SCALEPACK ${ }^{28}$ was applied. The structure was solved by direct methods using SIR2004. ${ }^{31}$ Refinement was performed on a LINUX PC using SHELX-97. ${ }^{32}$ There were six $\mathrm{O}$ atom positions of lattice water molecules found in $\mathrm{Ga}$ (DO3A-xy-TPP) ${ }^{+}$. No hydrogen atom was included for these oxygen atoms for which only the isotropic thermal parameter was refined. Crystallographic drawings were done using programs ORTEP, 33 and PLUTON. ${ }^{30}$ For $\mathrm{Mn}$ (DO3A-xy-TPP) $4 \mathrm{H}_{2} \mathrm{O} \cdot \mathrm{CH}_{3} \mathrm{OH}$, the cell constants for data collection were obtained from least-squares refinement, using the setting angles of 26583 reflections in the range $2<\lambda<26^{\circ}$. A total of 26583 reflections were collected and 6443 reflections were unique. Lorentz and polarization corrections were applied to the data. The linear absorption coefficient is $4.1 \mathrm{~cm}^{-1}$ for Mo $\mathrm{K}_{\alpha}$ radiation. An empirical absorption correction using SCALEPACK $^{28}$ was applied. The structure was solved by direct methods using SIR2004. ${ }^{31}$ Refinement was performed on a LINUX PC using SHELX-97. ${ }^{32}$ Crystallographic drawings were done using programs ORTEP. ${ }^{33}$ 


\section{RESULTS}

\section{Synthesis}

In this study, we prepared Ga(DO3A-xy-TPP) ${ }^{+}, \operatorname{In}(\mathrm{DO} 3 \mathrm{~A}-\mathrm{xy}-\mathrm{TPP})^{+}$and $\mathrm{Mn}(\mathrm{DO} 3 \mathrm{~A}-\mathrm{xy}-\mathrm{TPP})$ by reacting DO3A-xy-TPP with one equivalent of the respective metal salt in $0.5 \mathrm{M}$ ammonium acetate buffer $(\mathrm{pH}=6)$. Heating was needed to complete the reaction. $\mathrm{Ga}(\mathrm{DO} 3 \mathrm{~A}-\mathrm{xy}-\mathrm{TPP})^{+}$ and In(DO3A-xy-TPP) ${ }^{+}$were designed as model compounds for ${ }^{67 / 68} \mathrm{Ga}(\mathrm{DO} 3 \mathrm{~A}-\mathrm{xy}-\mathrm{TPP})^{+}$ and ${ }^{111} \operatorname{In}(\mathrm{DO} 3 \mathrm{~A}-\mathrm{xy}-\mathrm{TPP})^{+}$, respectively. Mn(DO3A-xy-TPP) was prepared due to its potential as a MRI contrast agent, and its similarity to that of the $\mathrm{Cu}(\mathrm{II})$ analog with respect to molecular charge and lipophilicity. ${ }^{26}$ Both $\mathrm{In}(\mathrm{DO} 3 \mathrm{~A}-\mathrm{xy}-\mathrm{TPP})^{+}$and $\mathrm{Ga}(\mathrm{DO} 3 \mathrm{~A}-\mathrm{xy}-\mathrm{TPP})^{+}$were isolated as the complex cations with acetate and nitrate as counter ions, respectively. $\mathrm{Mn}$ (DO3A-xyTPP) was obtained as the Zwitterion salt. All three compounds have been characterized by IR, ESI-MS, HPLC, elemental analysis and X-ray crystallography. In(DO3A-xy-TPP) ${ }^{+}$and Ga (DO3A-xy-TPP) ${ }^{+}$have also been studied by NMR spectroscopic methods $\left({ }^{1} \mathrm{H},{ }^{13} \mathrm{C},{ }^{31} \mathrm{P},{ }^{1} \mathrm{H}-{ }^{1} \mathrm{H}\right.$ COSY, HSQC, HMQC, HMBC, NOESY) in order to determine their solution structures.

\section{IR and ESI-MS}

The IR spectrum of In(DO3A-xy-TPP)(OAc) shows a strong and broad band at $3435 \mathrm{~cm}^{-1}$ due to $v_{\mathrm{O}-\mathrm{H}}$ of crystallization water molecules, and a strong band at $1630 \mathrm{~cm}^{-1}$ from the coordinated carboxylate groups. Upon coordination, stretching frequencies from the carboxylic groups $\left(v_{\mathrm{C}=\mathrm{O}} \sim 1730 \mathrm{~cm}^{-1}\right)$ undergo a significant "red-shift" $\left(\sim 100 \mathrm{~cm}^{-1}\right)$. The IR spectra of complexes $\mathrm{Ga}$ (DO3A-xy-TPP) $\left(\mathrm{NO}_{3}\right)$ and $\mathrm{Mn}$ (DO3A-xy-TPP) also show broad bands at $3441 \mathrm{~cm}^{-1}$ and $3429 \mathrm{~cm}^{-1}$, respectively, due to crystallization water molecules, a strong band at $1633 \mathrm{~cm}^{-1}$ for $\mathrm{Ga}(\mathrm{DO} 3 \mathrm{~A}-\mathrm{xy}-\mathrm{TPP})\left(\mathrm{NO}_{3}\right)$ and $1637 \mathrm{~cm}^{-1}$ for $\mathrm{Mn}(\mathrm{DO} 3 \mathrm{~A}-\mathrm{xy}-\mathrm{TPP})$ due to the coordinated carboxylate groups. A strong band at $1727 \mathrm{~cm}^{-1}$ was observed for the uncoordinated carboxylate group in $\mathrm{Ga}(\mathrm{DO} 3 \mathrm{~A}-\mathrm{xy}-\mathrm{TPP})\left(\mathrm{NO}_{3}\right)$. Two strong bands at $1300 \mathrm{~cm}^{-1}$ and 1412 $\mathrm{cm}^{-1}$ are typical of non-coordinating $\mathrm{NO}_{3}{ }^{-}$counter ions in $\mathrm{Ga}(\mathrm{DO} 3 \mathrm{~A}-\mathrm{xy}-\mathrm{TPP})\left(\mathrm{NO}_{3}\right)$. The ESI-MS of In(DO3A-xy-TPP)(OAc) shows a molecular ion at $m / z=823.16$ for $[\mathrm{M}+\mathrm{H}]^{+}$while the ESI-MS of $\mathrm{Ga}(\mathrm{DO} 3 \mathrm{~A}-\mathrm{xy}-\mathrm{TPP})\left(\mathrm{NO}_{3}\right)$ has the molecular ion at $\mathrm{m} / z=777.02$ for $[\mathrm{M}+\mathrm{H}]^{+}$. $\mathrm{Mn}$ (DO3A-xy-TPP) displays the molecular ion at $\mathrm{m} / z=764.09$ for $[\mathrm{M}+\mathrm{H}]^{+}$in its ESI mass spectrum.

\section{HPLC analysis}

The same HPLC method was used to determine relative lipophilicity of Ga(DO3A-xyTPP $)^{+}, \operatorname{In}(\text { DO3A-xy-TPP })^{+}$and Mn(DO3A-xy-TPP). Figure 2 illustrates their representative HPLC chromatograms. The presence of a single peak in the region of interest suggests that they exist in solution as a single or "averaged" species under the chromatographic conditions used in this study. The HPLC retention times for In(DO3A-xy-TPP) ${ }^{+}$and Ga(DO3A-xy$\mathrm{TPP})^{+}$are almost identical (14.5 and $14.7 \mathrm{~min}$, respectively); but they are significantly shorted than that of Mn(DO3A-xy-TPP) (16.8 min). Obviously, Ga(DO3A-xy-TPP) ${ }^{+}$and In(DO3A$\mathrm{xy}-\mathrm{TPP})^{+}$with the +1 overall molecular charge are more hydrophilic (shorter HPLC retention time) than Mn(DO3A-xy-TPP) in the Zwitterion form. The HPLC retention time of Mn(DO3A$\mathrm{xy}-\mathrm{TPP})$ is very close to that of $\mathrm{Cu}(\mathrm{DO} 3 \mathrm{~A}-\mathrm{xy}-\mathrm{TPP})(17.2 \mathrm{~min})$ under identical chromatographic conditions. 26

\section{HPLC Concordance Experiment}

The HPLC concordance experiment was performed using the HPLC-purified ${ }^{111} \operatorname{In}(\mathrm{DO} 3 \mathrm{~A}-\mathrm{xy}$ TPP) and In(DO3A-xy-TPP). Figure 3 shows HPLC chromatograms of In(DO3A-xy-TPP) ${ }^{+}$ (top) and ${ }^{111} \operatorname{In}(\mathrm{DO} 3 \mathrm{~A}-\mathrm{xy}-\mathrm{TPP})^{+}$(bottom) under the same chromatographic conditions. Since 
they share almost identical HPLC retention times, we believe that ${ }^{111} \operatorname{In}(\mathrm{DO} 3 \mathrm{~A}-\mathrm{xy}-\mathrm{TPP})^{+}$and In(DO3A-xy-TPP $)^{+}$have the same composition at both tracer and macroscopic levels.

\section{Structure of $\ln (\mathrm{DO} 3 \mathrm{~A}-\mathrm{xy}-\mathrm{TPP})^{+}$}

Figure 4 illustrates an ORTEP view of In(DO3A-xy-TPP) ${ }^{+}$. There are two In(DO3A-xy-TPP) $(\mathrm{OAc})$ molecules in each unit cell, along with eight crystallization water molecules and one acetone surrounding each $\operatorname{In}(\mathrm{DO} 3 \mathrm{~A}-\mathrm{xy}-\mathrm{TPP})^{+}$. DO3A acts as a heptadentate ligand in bonding to In(III) with four amine-N, three carboxylate-O donor atoms. The coordination geometry in In(DO3A-xy-TPP $)^{+}$is best described as the monocapped octahedron in which three amine- $\mathrm{N}$ atoms, $\mathrm{N}(1), \mathrm{N}(4), \mathrm{N}(10)$, and three oxygen atoms, $\mathrm{O}(41), \mathrm{O}(71), \mathrm{O}(101)$, from the carboxylate groups. The atom $\mathrm{N}(7)$ caps the triangular face formed by $\mathrm{N}(4), \mathrm{N}(10)$ and $\mathrm{O}(71)$. In(DO3Axy-TPP $)^{+}$has a symmetry plane that is defined by four atoms: $\mathrm{N}(1), \operatorname{In}(51), \mathrm{N}(7)$ and $\mathrm{O}(71)$. The structure of $\operatorname{In}(\mathrm{DO} 3 \mathrm{~A}-\mathrm{xy}-\mathrm{TPP})^{+}$is very similar to that of $\mathrm{Na}[\operatorname{In}(\mathrm{L} 1)]\left(\mathrm{NO}_{3}\right)\left(\mathrm{H}_{2} \mathrm{O}\right)$ $\left(\mathrm{C}_{2} \mathrm{H}_{5} \mathrm{OH}\right) \cdot 2.65 \mathrm{H}_{2} \mathrm{O}\left(\mathrm{H}_{3} \mathrm{~L} 1=\operatorname{tris}\left(2^{\prime}\right.\right.$-hydroxybenzylaminoethyl $)$ amine $),{ }^{34}$ and [ $\left.\operatorname{In}(\mathrm{DO} 3 \mathrm{~A})\right]$ $\cdot 2 \mathrm{H}_{2} \mathrm{O} \cdot \mathrm{MeOH} .{ }^{35}$

Table 3 lists selected In- $\mathrm{N}$ and In-O bond distances and selected bond angles in $\mathrm{In}(\mathrm{DO} 3 \mathrm{~A}-\mathrm{xy}-$ $\mathrm{TPP})^{+}$. The average In-N bond length is $2.374 \AA$ ( $\operatorname{In}(51)-\mathrm{N}(1): 2.375(4), \operatorname{In}(51)-\mathrm{N}(4): 2.399$ (4), $\operatorname{In}(51)-\mathrm{N}(10): 2.327(4) \AA, \operatorname{In}(51)-\mathrm{N}(7): 2.395(4) \AA)$ ), which is close to that (average In-N distance $=2.356 \AA$ ) of $\operatorname{In}(\mathrm{DO} 3 \mathrm{~A}) \cdot 2 \mathrm{H}_{2} \mathrm{O} \cdot \mathrm{MeOH}, 35$ and is slightly shorter than that (average In-N distance $=2.430 \AA$ ) of In(DOTA-AA) (DOTA-AA $=1,4,7,10$ -

tetraazacyclododecane-1,4,7,10-tetraacetic acid mono( $p$-aminoanilide) $)$ due to its smaller coordination number. ${ }^{36}$ The average In-O bond length is $2.174 \AA(\operatorname{In}(51)-\mathrm{O}(41): 2.159(3) \AA$, $\operatorname{In}(51)-\mathrm{O}(71): 2.162(3) \AA$, and $\operatorname{In}(51)-\mathrm{O}(101): 2.202(3) \AA)$, which is comparable to that observed in $\mathrm{In}(\mathrm{DO} 3 \mathrm{~A}) \cdot 2 \mathrm{H}_{2} \mathrm{O} \cdot \mathrm{MeOH}$ (average In-O distance $=2.181 \AA$ ),${ }^{35}$ but it is shorter than that of In(DOTA-AA) (average In-O distance $=2.2191 \AA$ ). ${ }^{36}$ The N(7) amine-nitrogen atom caps the triangular face formed by $\mathrm{N}(4), \mathrm{N}(10)$ and $\mathrm{O}(71)$, leading to the enlarged triangular face $\left(\mathrm{O}(71)-\operatorname{In}(51)-\mathrm{N}(4)=114.19(13)^{\circ}, \mathrm{N}(10)-\operatorname{In}(51)-\mathrm{N}(4)=120.38(14)^{\circ}, \mathrm{O}(71)-\operatorname{In}(51)-\mathrm{N}(10)\right.$ $\left.=103.51(14)^{\circ}\right)$ and the reduced triangular face formed by $\mathrm{N}(1), \mathrm{O}(41)$ and $\mathrm{O}(101)(\mathrm{O}(41)-\mathrm{In}$ $(51)-\mathrm{N}(1)=86.06(13)^{\circ}, \mathrm{O}(101)-\operatorname{In}(51)-\mathrm{N}(1)=86.55(13)^{\circ}$ and $\mathrm{O}(41)-\operatorname{In}(51)-\mathrm{O}(101)=84.51$ $\left.(12)^{\circ}\right)$. The $\operatorname{In}(51)-\mathrm{N}(7)$ bond distance is $2.395(4) \AA$, which is significantly shorter than that $(\operatorname{In}(1)-\mathrm{N}(7)=2.752(4) \AA)$ in $\mathrm{Na}[\mathrm{In}(\mathrm{L} 1)]\left(\mathrm{NO}_{3}\right)\left(\mathrm{H}_{2} \mathrm{O}\right)\left(\mathrm{C}_{2} \mathrm{H}_{5} \mathrm{OH}\right) \cdot 2.65 \mathrm{H}_{2} \mathrm{O} .{ }^{34}$

\section{Structure of $\mathrm{Ga}(\mathrm{DO} 3 \mathrm{~A}-\mathrm{xy}-\mathrm{TPP})^{+}$}

Figure 5 shows the ORTEP view of $\mathrm{Ga}(\mathrm{DO} 3 \mathrm{~A}-\mathrm{xy}-\mathrm{TPP})^{+}$. In each unit cell, there are four $\mathrm{Ga}$ (DO3A-xy-TPP) $\left(\mathrm{NO}_{3}\right)$ molecules, along with six crystallization water molecules and one acetone surrounding each $\mathrm{Ga}(\mathrm{DO} 3 \mathrm{~A}-\mathrm{xy}-\mathrm{TPP})\left(\mathrm{NO}_{3}\right)$. The coordinated DO3A is hexadentate with four amine-N, two carboxylate-O donor atoms bonding to $\mathrm{Ga}(\mathrm{III})$ due to its smaller size than that of In(III). The remaining acetic acid group is uncoordinated and deprotonated to balance the positive charge of $\mathrm{Ga}(\mathrm{III})$. The coordination geometry around the $\mathrm{Ga}$ (III) is best described as a distorted octahedron with $\mathrm{N}(4), \mathrm{N}(10), \mathrm{O}(41)$ and $\mathrm{O}(101)$ forming the equatorial plane, $\mathrm{N}(1)$ and $\mathrm{N}(7)$ occupying the remaining two axial positions. The structure of $\mathrm{Ga}(\mathrm{DO} 3 \mathrm{~A}-$ xy-TPP $)^{+}$is very similar to that reported for $\mathrm{Ga}\left(\right.$ DOTA-D-PheNH $\left.\mathrm{N}_{2}\right)\left(\right.$ DOTA-D-PheNH ${ }_{2}=$ 1,4,7,10-Tetraazacyclododecane-4,7,10-tricarboxymethyl-1-yl-acetyl-D-Phe- $\left.\mathrm{NH}_{2}\right),{ }^{37} \mathrm{Ga}$ (HDOTA) $5.5 \mathrm{H}_{2} \mathrm{O}$ (DOTA = 1,4,7,10-tetraazacyclododecane-4,7,10-triacetic acid), ${ }^{38}[\mathrm{Ga}$ (Brbad) $\mathrm{ClO}_{4}$. DMSO $\left(\mathrm{H}_{2} \mathrm{Brbad}=1,10\right.$-bis(2-hydroxy-5-bromobenzyl)-1,4,7,10tetraazadecane), ${ }^{39}$ and $[\mathrm{Ga}(\mathrm{HL} 3)] \mathrm{Cl} \cdot \mathrm{CHCl}_{3}\left(\mathrm{H}_{3} \mathrm{~L} 3=\right.$ tris $\left(5^{\prime}\right.$-bromo-2'hydroxybenzylaminoethyl)amine). ${ }^{34}$ There is a symmetry plane that is defined by $\mathrm{N}(1), \mathrm{Ga}$ (1) and $\mathrm{N}(7)$, divide s the coordinated DO3A moiety into two identical part. As a result, the bond angle $\mathrm{N}(10)-\mathrm{Ga}(1)-\mathrm{N}(7)\left(83.35(11)^{\circ}\right)$ is almost identical to that of $\mathrm{N}(4)-\mathrm{Ga}(1)-\mathrm{N}(7)$ $\left(83.52(12)^{\circ}\right)$ while the bond angle $\mathrm{N}(10)-\mathrm{Ga}(1)-\mathrm{N}(1)\left(82.72(11)^{\circ}\right)$ is very close to the angle $\mathrm{N}$ (4)- $\mathrm{Ga}(1)-\mathrm{N}(1)\left(83.10(12)^{\circ}\right)$. 
Table 4 lists the selected bond distances and bond angles in $\mathrm{Ga}(\mathrm{DO} 3 \mathrm{~A}-\mathrm{xy}-\mathrm{TPP})^{+}$. The average Ga-N bond length is $2.127 \AA$ (Ga(1)-N(4): 2.115(3) $\AA, \mathrm{Ga}(1)-\mathrm{N}(10): 2.122(3) \AA, \mathrm{Ga}(1)-\mathrm{N}(7)$ : 2.125(3) $\AA, \mathrm{Ga}(1)-\mathrm{N}(1): 2.147(2) \AA$ ), which is very similar to that of $\mathrm{Ga}(\mathrm{HDOTA}) \cdot 5.5 \mathrm{H}_{2} \mathrm{O}$ (average Ga-N distance $=2.123 \AA$ ),${ }^{38}[\mathrm{Ga}(\mathrm{Brbad})] \mathrm{ClO}_{4} \cdot \mathrm{DMSO}$ (average Ga-N distance $=$ $2.112 \AA),{ }^{39}[\mathrm{Ga}(\mathrm{HL} 3)] \mathrm{Cl} \cdot \mathrm{CHCl}_{3}$ (average Ga-N distance $\left.=2.113 \AA\right)^{34}$ and is slightly shorter than that 37 of $\mathrm{Ga}\left(\mathrm{DOTA}-\mathrm{D}-\mathrm{PheNH}_{2}\right)($ average Ga-N distance $=2.141 \AA$ ). The equatorial Ga$\mathrm{N}$ bonds $(2.125(3) \AA$ and $2.147(2) \AA)$ are slightly longer than the axial ones $(2.115(3) \AA$ and 2.122(3) $\AA$ ). The average Ga-O bond length is $1.930 \AA$ (Ga(1)-O(41): 1.926(2) $\mathrm{A}, \mathrm{Ga}(1)-\mathrm{O}$ (101): $1.934(3) \AA$ ), which is very close to that of $\mathrm{Ga}(\mathrm{HDOTA}) \cdot 5.5 \mathrm{H}_{2} \mathrm{O}(1.935 \AA), 38$ and slightly longer than that of $[\mathrm{Ga}(\mathrm{Brbad})] \mathrm{ClO}_{4} \cdot \mathrm{DMSO}(1.913 \AA),{ }^{39}[\mathrm{Ga}(\mathrm{HL} 3)] \mathrm{Cl} \cdot \mathrm{CHCl}_{3}(1.901$ $\AA)^{34}$ and $\mathrm{Ga}\left(\right.$ DOTA-D- $\left.\mathrm{PheNH}_{2}\right)(1.918 \AA)$. ${ }^{37}$

\section{Structure of Mn(DO3A-xy-TPP)}

A representative ORTEP view of Mn(DO3A-xy-TPP) is shown in Figure 6. Crystallization water molecules and hydrogen atoms are omitted for the sake of clarity. In general, there are four $\mathrm{Mn}(\mathrm{DO} 3 \mathrm{~A}-\mathrm{xy}-\mathrm{TPP})$ molecules in each unit cell, along with four crystallization water molecules and one methanol molecule surrounding each Mn(DO3A-xy-TPP). Like that in In $(\text { DO3A-xy-TPP })^{+}$, DO3A is heptadentate with all four amine-N, three carboxylate-O atoms bonding to the $\mathrm{Mn}(\mathrm{II})$. There is a symmetry plane defined by $\mathrm{N}(1), \mathrm{Mn}, \mathrm{N}(7)$ and $\mathrm{O}(71)$ in the coordinated DO3A. The coordination geometry of $\mathrm{Mn}(\mathrm{DO} 3 \mathrm{~A}-\mathrm{xy}-\mathrm{TPP})$ is very similar to that of $\operatorname{In}(\mathrm{DO} 3 \mathrm{~A}-\mathrm{xy}-\mathrm{TPP})^{+}$. Three amine-N atoms, $\mathrm{N}(1), \mathrm{N}(4)$ and $\mathrm{N}(10)$, and three carboxylate$\mathrm{O}, \mathrm{O}(43), \mathrm{O}(73)$ and $\mathrm{O}(103)$, form the distorted octahedron. The remaining amine- $\mathrm{N}$ atom, $\mathrm{N}$ (7), caps the triangular face formed by $\mathrm{N}(4), \mathrm{N}(10)$ and $\mathrm{O}(73)$.

Table 5 lists selected $\mathrm{Mn}-\mathrm{N}$ and $\mathrm{Mn}-\mathrm{O}$ bond distances and selected bond angles in the coordination sphere $\mathrm{Mn}(\mathrm{DO} 3 \mathrm{~A}-\mathrm{xy}-\mathrm{TPP})$. The average Mn-N bond length is $2.426 \AA$ (Mn-N (1): 2.447(3) $\AA, \mathrm{Mn}-\mathrm{N}(4): 2.379(3) \AA, \mathrm{Mn}-\mathrm{N}(10): 2.421(3) \AA$, Mn-N(7): 2.455(3) $\mathrm{A})$, which is in agreement with those previous reported. ${ }^{40,} 41$ The average Mn-O bond length is 2.182 $\AA$ (Mn-O(43): 2.196(3) $\AA, \mathrm{Mn}-\mathrm{O}(73): 2.190(3) \AA$, Mn-O(103): 2.161(3) $\AA$ ), which is slightly shorter than that of $[\mathrm{Mn}(\mathrm{EDTB})(\mathrm{Ac})](\mathrm{Ac}) \cdot \mathrm{C}_{2} \mathrm{H}_{5} \mathrm{OH}\left(\mathrm{EDTB}=N, N, N^{\prime}, N^{\prime}\right.$-tetrakis $\left(2^{\prime}-\right.$ benzimidazolylmethyl)-1,2-ethanediamine). ${ }^{41}$ The Mn-N(7) bond distance is $2.455(3) \AA$ with $\mathrm{N}(7)$ capping the triangular face formed by $\mathrm{N}(4), \mathrm{N}(10), \mathrm{O}(73)$, which leads to an increase of the triangular face $\left(\mathrm{N}(4)-\mathrm{Mn}-\mathrm{O}(73)=110.85(12)^{\circ}, \mathrm{N}(4)-\mathrm{Mn}-\mathrm{N}(10)=116.45(12)^{\circ}, \mathrm{N}(10)-\mathrm{Mn}-\right.$ $\left.\mathrm{O}(73)=107.81(12)^{\circ}\right)$ and a decrease of the triangular face formed by $\mathrm{N}(1), \mathrm{O}(43)$, and $\mathrm{O}(103)$ $\left(\mathrm{N}(1)-\mathrm{Mn}-\mathrm{O}(43)=90.23(12)^{\circ}, \mathrm{N}(1)-\mathrm{Mn}-\mathrm{O}(103)=82.34(11)^{\circ}, \mathrm{O}(103)-\mathrm{Mn}-\mathrm{O}(43)=87.98\right.$ $\left.(10)^{\circ}\right)$ in the octahedron. The coordination numbers of $\mathrm{Mn}(\mathrm{II})$ complexes range from four to eight. ${ }^{44}$ Seven-coordinated $\mathrm{Mn}$ (II) complexes normally have the coordination geometry of either monocapped octahedron or a pentagonal bipyramid. $39-43,45-47$

\section{NMR for In(DO3A-xy-TPP) ${ }^{+}$and Ga(DO3A-xy-TPP) ${ }^{+}$}

Since ${ }^{111} \mathrm{In}(\mathrm{DO} 3 \mathrm{~A}-\mathrm{xy}-\mathrm{TPP})^{+}$and ${ }^{67 / 68} \mathrm{Ga}(\mathrm{DO} 3 \mathrm{~A}-\mathrm{xy}-\mathrm{TPP})^{+}$are used as radiotracers in biological systems, it is necessary to study their solution properties (structure, isomerism and stability) in aqueous solution. The solution structures of $\operatorname{In}(\mathrm{DO} 3 \mathrm{~A}-\mathrm{xy}-\mathrm{TPP})^{+}$and $\mathrm{Ga}(\mathrm{DO} 3 \mathrm{~A}-$ xy-TPP $)^{+}$were elucidated using NMR methods $\left({ }^{1} \mathrm{H},{ }^{13} \mathrm{C},{ }^{1} \mathrm{H}-{ }^{1} \mathrm{H}\right.$ COSY, HSQC, HMQC, HMBC and NOESY) while isomerism and stability were monitored by variable temperature ${ }^{1} \mathrm{H}$ NMR spectroscopy. Table 1 summarizes ${ }^{1} \mathrm{H}$ NMR and ${ }^{13} \mathrm{C}$ NMR data for In

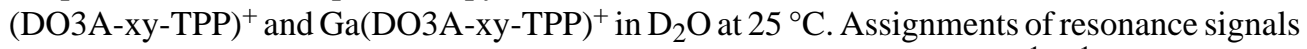
from phenyl, $p$-xylene and acetate groups were based on results from the ${ }^{1} \mathrm{H}^{1}{ }^{1} \mathrm{H} \mathrm{COSY}$, NOESY, HSQC and HMQC experiments at $25^{\circ} \mathrm{C}$ (Figures SI -SVI). The assignment of resonance signals from protons of the cyclen backbone was tentative due to the fact that many of them are superimposed. 
Figure 7 shows the aliphatic region of ${ }^{1} \mathrm{H}$ NMR spectra of $\operatorname{In}(\mathrm{DO} 3 \mathrm{~A}-\mathrm{xy}-\mathrm{TPP})^{+}$in $\mathrm{D}_{2} \mathrm{O}$ at $5^{\circ}$ $\mathrm{C}$ (top) and $25^{\circ} \mathrm{C}$ (bottom). The doublet at $4.73 \mathrm{ppm}$ is assigned to $\mathrm{H} 14$ and $\mathrm{H} 14^{\prime}$ of the $\mathrm{PCH}_{2} \mathrm{C}_{6} \mathrm{H}_{4}$ moiety. Splitting is caused by coupling from the phosphonium-P. The singlet at $3.96 \mathrm{ppm}$ is from $\mathrm{H} 9$ and $\mathrm{H}^{\prime}$ of the $\mathrm{NCH}_{2} \mathrm{C}_{6} \mathrm{H}_{4}$ moiety. The singlet at 3.53 is from $\mathrm{H} 2 \mathrm{a}$ and $\mathrm{H} 2 \mathrm{~b}$ in the acetate chelating arm attached to $\mathrm{N}(7)$. The $\mathrm{AB}$ quartet at $\sim 3.6 \mathrm{ppm}$ is assigned to H5a, H5b, H5a' and H5b' of the two opposite acetate chelating arms. The multiplets at 3.33 ppm and 3.09 ppm are tentatively assigned to $\mathrm{H} 3 \mathrm{a}, \mathrm{H} 3 \mathrm{a}^{\prime}, \mathrm{H} 3 \mathrm{~b}$ and $\mathrm{H} 3 \mathrm{~b}^{\prime}$ of the macrocycle. The multiplets at $3.25 \mathrm{ppm}$ and $3.04 \mathrm{ppm}$ are most likely from eight methylene protons (H4, H4', $\mathrm{H} 7$ and $\mathrm{H}^{\prime}$ ) while the broad peak at $2.69 \mathrm{ppm}$ are probably from the other methylene protons (H8a, H8a', H8b and H8b') of the cyclen macrocycle. As the temperature increases from $5{ }^{\circ} \mathrm{C}$ to $25^{\circ} \mathrm{C}$, all signals become sharper with no significant change in their chemical shifts.

Figure 8 shows the aliphatic region of ${ }^{1} \mathrm{H}$ NMR spectra of $\mathrm{Ga}\left(\right.$ DOTA-xy-TPP) ${ }^{+}$in $\mathrm{D}_{2} \mathrm{O}$ at 25 ${ }^{\circ} \mathrm{C}$ (top) and $65^{\circ} \mathrm{C}$ (bottom). The doublet at $4.78 \mathrm{ppm}$ is assigned to $\mathrm{H} 14$ and $\mathrm{H} 14^{\prime}$ ' of the $\mathrm{PCH}_{2} \mathrm{C}_{6} \mathrm{H}_{4}$ moiety. The singlet at $3.92 \mathrm{ppm}$ is from $\mathrm{H} 9$ and $\mathrm{H} 9^{\prime}$ of the $\mathrm{NCH}_{2} \mathrm{C}_{6} \mathrm{H}_{4}$ moiety. The singlet at 3.49 is assigned to methylene protons $(\mathrm{H} 2 \mathrm{a}$ and $\mathrm{H} 2 \mathrm{~b})$ in the uncoordinated acetate group. The $\mathrm{AB}$ quartet at $\sim 3.85 \mathrm{ppm}$ are from four methylene protons (H5a and $\mathrm{H} 5^{\prime}$ ) in the two opposite acetate chelating arms due to the asymmetric nature of Ga(DOTA-xy-TPP) ${ }^{+}$. The multiplets at $4.02 \mathrm{ppm}$ and $3.26 \mathrm{ppm}$ are tentatively assigned to methylene protons ( $\mathrm{H} 3 \mathrm{a}, \mathrm{H} 3 \mathrm{a}$ ', $\mathrm{H} 3 \mathrm{~b}$ and $\mathrm{H} 3 \mathrm{~b}$ ') of the cyclen macrocycle. The multiplets at $3.35 \mathrm{ppm}$ and $3.51 \mathrm{ppm}$ are from eight methylene protons ( $\mathrm{H} 4, \mathrm{H} 4^{\prime}, \mathrm{H} 7$ and $\left.\mathrm{H}^{\prime}\right)$ and the multiplet at $2.89 \mathrm{ppm}$ and $3.39 \mathrm{ppm}$ are from remaining four methylene protons $\left(\mathrm{H} 8 \mathrm{a}, \mathrm{H} 8 \mathrm{a}^{\prime}, \mathrm{H} 8 \mathrm{~b}\right.$ and $\left.\mathrm{H}^{\circ} \mathrm{b}^{\prime}\right)$ on the macrocyclic framework. As the temperature increases from $25^{\circ} \mathrm{C}$ to $65^{\circ} \mathrm{C}$, all proton resonance signals remain the same except the multiplet at $4.0 \mathrm{ppm}$ shifted to $3.9 \mathrm{ppm}$ probably due to rapid inversion of ethylenic groups on the cyclen macrocycle.

\section{DISCUSSION}

This report describes synthesis and structural characterization of $\mathrm{Ga}(\mathrm{DO} 3 \mathrm{~A}-\mathrm{xy}-\mathrm{TPP})^{+}$, In (DO3A-xy-TPP) ${ }^{+}$and Mn(DO3A-xy-TPP). The most important finding from this study is that the bonding mode of DO3A depends largely on the size of metal ion. For example, the ionic radius of $\mathrm{In}(\mathrm{III})$ is $0.92 \AA,{ }^{48}$ and DO3A is heptadentate in $\mathrm{In}(\mathrm{DO} 3 \mathrm{~A}-\mathrm{xy}-\mathrm{TPP})^{+}$. Mn(II) has an ionic radius of $0.90 \AA$, and the coordination geometry around $\mathrm{Mn}(\mathrm{II})$ in $\mathrm{Mn}(\mathrm{DO} 3 \mathrm{~A}-\mathrm{xy}$-TPP) is almost identical to that in $\operatorname{In}(\mathrm{DO} 3 \mathrm{~A}-\mathrm{xy}-\mathrm{TPP})^{+}$in spite of their charge difference. $\mathrm{Ga}$ (III) has a much smaller ionic radius $(0.62 \AA) .{ }^{48}$ As a result, coordinated DO3A is hexadentate with one acetate group remaining deprotonated in $\mathrm{Ga}(\mathrm{DO} 3 \mathrm{~A}-\mathrm{xy}-\mathrm{TPP})^{+}$. The overall molecular charge of $\mathrm{Ga}(\mathrm{DO} 3 \mathrm{~A}-\mathrm{xy}-\mathrm{TPP})^{+}$is the same as that of $\operatorname{In}(\mathrm{DO} 3 \mathrm{~A}-\mathrm{xy}-\mathrm{TPP})^{+}$.

The solution structure of $\operatorname{In}(\mathrm{DO} 3 \mathrm{~A}-\mathrm{xy}-\mathrm{TPP})^{+}$and $\mathrm{Ga}(\mathrm{DO} 3 \mathrm{~A}-\mathrm{xy}-\mathrm{TPP})^{+}$is important for understanding the coordination chemistry of DO3A-conjugated TPP cations with ${ }^{67 / 68} \mathrm{Ga}$ and ${ }^{111} \mathrm{In}$ at the tracer level. On the basis of HPLC concordance experiments, it is concluded that ${ }^{111} \operatorname{In}(\mathrm{DO} 3 \mathrm{~A}-\mathrm{xy}-\mathrm{TPP})^{+}$and $\operatorname{In}(\mathrm{DO} 3 \mathrm{~A}-\mathrm{xy}-\mathrm{TPP})^{+}$have the same composition due to their identical HPLC retention times (Figure 3). In(DO3A-xy-TPP) ${ }^{+}$remains symmetrical in aqueous solution. This conclusion is supported by the fact that the proton resonance signals from the $\mathrm{NCH}_{2} \mathrm{C}_{6} \mathrm{H}_{4}$ moiety and the acetate arm attached to $\mathrm{N}(7)$ appear as two singlets at 3.96 ppm and $3.53 \mathrm{ppm}$, respectively. The presence of the $\mathrm{AB}$ quartet at $\sim 3.62 \mathrm{ppm}$ clearly indicates that all three carboxylate-O donors are firmly bonded to In(III). If these carboxylate-O donors were dissociated, there would have been three singlets: one from the central acetate group, one from the $\mathrm{NCH}_{2} \mathrm{C}_{6} \mathrm{H}_{4}$ moiety, and one from the two remaining acetate arms.

This symmetrical structure $\mathrm{Ga}(\mathrm{DO} 3 \mathrm{~A}-\mathrm{xy}-\mathrm{TPP})^{+}$is also maintained in solution as evidenced by the presence of two singlets at $3.92 \mathrm{ppm}$ and $3.54 \mathrm{ppm}$ from the $\mathrm{NCH}_{2} \mathrm{C}_{6} \mathrm{H}_{4}$ moiety and the acetate arm attached to N(7), respectively. Since the two methylene hydrogens of the 
coordinated acetate chelating arms experience different chemical environments, it is not surprising that they appear as the $\mathrm{AB}$ quartet at $\sim 3.65 \mathrm{ppm}$. The two coordinated carboxylate$\mathrm{O}$ donor atoms remain firmly bonded to $\mathrm{Ga}(\mathrm{III})$ even at $65^{\circ} \mathrm{C}$ (Figure 4 ), suggesting that ${ }^{68} \mathrm{Ga}$ $(\mathrm{DO} 3 \mathrm{~A}-\mathrm{xy}-\mathrm{TPP})^{+}$might have a very high in vivo solution stability as observed for ${ }^{68} \mathrm{Ga}$ $\left(\text { DOTA-D-Phe- } \mathrm{NH}_{2}\right)^{+} .37$

Comparison of the ${ }^{1} \mathrm{H}$ NMR spectra (Figures 7 and 8) of $\operatorname{In}(\mathrm{DO} 3 \mathrm{~A}-\mathrm{xy}-\mathrm{TPP})^{+}$and $\mathrm{Ga}(\mathrm{DOTA}-$ xy-TPP) $)^{+}$reveals certain similarities in the splitting patterns for $\mathrm{H} 2, \mathrm{H} 5, \mathrm{H} 9$ and $\mathrm{H} 14$, as well as significant differences in chemical shifts of $\mathrm{H} 3, \mathrm{H} 4, \mathrm{H} 7$ and $\mathrm{H} 8$. The fact that both $\mathrm{H} 3 \mathrm{a}$ and H8a have significantly different chemical shifts (Table 1) in the ${ }^{1} \mathrm{H}$ NMR spectra of In(DO3Axy-TPP $)^{+}$and $\mathrm{Ga}(\mathrm{DOTA}-\mathrm{xy}-\mathrm{TPP})^{+}$strongly suggests that they might have different solution structures as those (Figures 4 and 5) observed in the solid state. It is important to note that the most common coordination number for In(III) is 6 and/or 7 while the coordination number of $\mathrm{Ga}$ (III) is predominantly 6 due to its smaller ionic radius. $34,35,38,39,48$ Therefore, it is reasonable to believe that the solution structure of $\mathrm{Ga}\left(\mathrm{DOTA}\right.$-xy-TPP) ${ }^{+}$is the same as that in the solid state (Figure 5) with one acetate chelating arm being uncoordinated.

\section{CONCLUSION}

In conclusion, $\mathrm{Ga}(\mathrm{DO} 3 \mathrm{~A}-\mathrm{xy}-\mathrm{TPP})^{+}, \mathrm{In}(\mathrm{DO} 3 \mathrm{~A}-\mathrm{xy}-\mathrm{TPP})^{+}$and $\mathrm{Mn}(\mathrm{DO} 3 \mathrm{~A}-\mathrm{xy}-\mathrm{TPP})$ have been prepared and characterized by elemental analysis, spectroscopic methods and $\mathrm{X}$-ray crystallography. In the solid state, DO3A uses all of its seven donor atoms $\left(\mathrm{N}_{4} \mathrm{O}_{3}\right)$ in bonding to In(III) or Mn(II) while it is only hexadentate in bonding to $\mathrm{Ga}(\mathrm{III})$ with four amine-N and only two carboxylate-O donor atoms. The NMR data clearly demonstrate that the coordinated DO3A in $\operatorname{In}(\mathrm{DO} 3 \mathrm{~A}-\mathrm{xy}-\mathrm{TPP})^{+}$and $\mathrm{Ga}(\mathrm{DO} 3 \mathrm{~A}-\mathrm{xy}-\mathrm{TPP})^{+}$is symmetrical in aqueous solution. The variable temperature ${ }^{1} \mathrm{H}$ NMR data reveal no dissociation of the two acetate chelating arms in $\mathrm{Ga}(\mathrm{DO} 3 \mathrm{~A}-\mathrm{xy}-\mathrm{TPP})^{+}$that remains rigid in aqueous solution even at temperatures over $65^{\circ}$ C.

An important finding from this study is that $\mathrm{Ga}(\mathrm{DO} 3 \mathrm{~A}-\mathrm{xy}-\mathrm{TPP})^{+}$and $\mathrm{In}(\mathrm{DO} 3 \mathrm{~A}-\mathrm{xy}-\mathrm{TPP})^{+}$are more hydrophilic than Mn(DO3A-xy-TPP), the HPLC retention time of which is very close to that of $\mathrm{Cu}$ (DO3A-xy-TPP). ${ }^{26}$ This suggests that $\mathrm{Cu}$ (DO3A-xy-TPP) may also exist in solution as its Zwitterion form as observed in Mn(DO3A-xy-TPP) despite of their difference in coordination number due to the smaller ionic radius of $\mathrm{Cu}$ (II) $(0.67 \AA)$ than $\mathrm{Mn}(\mathrm{II})(0.90 \AA)$. 48 Since the ionic radius of $\mathrm{Cu}(\mathrm{II})$ is very close to that of $\mathrm{Ga}(\mathrm{III})(0.62 \AA),{ }^{48}$ we believe that the coordinated DO3A in $\mathrm{Cu}(\mathrm{DO} 3 \mathrm{~A}-\mathrm{xy}-\mathrm{TPP})$ most likely hexadentate with one acetate group being deprotonated to balance to cationic charge from the TPP moiety. Evaluation of ra diometal chelate and overall molecular charge on biological properties of the radiolabeled TPP cation is still in progress, and the results from these studies will be reported elsewhere.

\section{Supplementary Material}

Refer to Web version on PubMed Central for supplementary material.

\section{Acknowledgements}

Acknowledgement is made to Dr. Huaping Mo for his help with NMR data analysis and to Dr. Philip E. Fanwick, Department of Chemistry, Purdue University, for X-ray crystallography of $\mathrm{In}(\mathrm{DO} 3 \mathrm{~A}-\mathrm{xy}-\mathrm{TPP})(\mathrm{OAc}) \cdot 7.5 \mathrm{H}_{2} \mathrm{O}$. $\left(\mathrm{CH}_{3}\right)_{2} \mathrm{CO}, \mathrm{Ga}(\mathrm{DO} 3 \mathrm{~A}-\mathrm{xy}-\mathrm{TPP})\left(\mathrm{NO}_{3}\right) \cdot 6 \mathrm{H}_{2} \mathrm{O} \cdot\left(\mathrm{CH}_{3}\right)_{2} \mathrm{CO}$ and $\mathrm{Mn}(\mathrm{DO} 3 \mathrm{~A}-\mathrm{xy}-\mathrm{TPP}) \cdot 4 \mathrm{H}_{2} \mathrm{O} \cdot \mathrm{CH}_{3} \mathrm{OH}$. This work is supported, in part, by Purdue University and research grants: 1R01 CA115883-01A2 (S.L.) from National Cancer Institute (NCI), BCTR0503947 (S.L.) from the Susan G. Komen Breast Cancer Foundation, AHA0555659Z (S.L.) from the Greater Midwest Affiliate of American Heart Association, R21 EB003419-02 (S.L.) from National Institute of Biomedical Imaging and Bioengineering (NIBIB) and R21 HL083961-01 from National Heart, Lung, and Blood Institute (NHLBI). 


\section{References}

1. Kroemer G, Dallaporta B, Resche-Rigon M. Annu Rev Physiol 1998;60:619-642. [PubMed: 9558479]

2. Modica-Napolitano JS, Aprille JR. Advanced Drug Delivery Reviews 2001;49:63-70. [PubMed: 11377803]

3. Duchen MR. Mol Aspects Med 2004;25:365-451. [PubMed: 15302203]

4. Modica-Napolitano, JS.; Singh, KK. Expert Reviews in Molecular Medicine. 2002. http://www.ermm.cbcu.cam.ac.uk(02)00445-3a (short code: txt001ksb)

5. Johnson LV, Walsh ML, Chen LB. Proc Natl Acad Sci USA 1980;77:990-994. [PubMed: 6965798]

6. Summerhayes IC, Lampidis TJ, Bernal SD, Nadakavukaren JJ, Nadakavukaren KK, Shepard EL, Chen LB. Proc Natl Acad Sci USA 1982;79:5292-5296. [PubMed: 6752944]

7. Modica-Napolitano JS, Aprille JR. Cancer Res 1987;47:4361-4365. [PubMed: 2886218]

8. Davis S, Weiss MJ, Wong JR, Lampidis TJ, Chen LB. J Biol Chem 1985;260:3844-3850. [PubMed: 3972850]

9. Dairkee SH, Hackett AJ. Breast Cancer Res Treat 1991;18:57-61. [PubMed: 1854980]

10. Gottlieb E, Thompson CB. Methods in Mol Biol 2003;223:543-554. [PubMed: 12777750]

11. Mannella CA. Biochim Biophys Acta 2006;1762:140-147. [PubMed: 16054341]

12. Ross MF, Kelso GF, Blaikie FH, James AM, Cocheme HM, Filipovska A, Da Ros TD, Hurd TR, Smith RAJ, Murphy MP. Biochem (Moscow) 2005;70:222-230.

13. Jakobs S. Biochim Biophys Acta 2006;1763:561-575. [PubMed: 16750866]

14. Lichtshtein D, Kaback HR, Blume AJ. Proc Natl Acad Sci USA 1979;76:650-654. [PubMed: 284390]

15. Hockings PD, Rogers PJ. Biochim Biophys Acta 1996;1282:101 -106. [PubMed: 8679645]

16. Huang SG. J Biomolecular Screening 2002;7:383-389.

17. Krause BJ, Szabo Z, Becker LC, Dannals RF, Scheffel U, Seki C, Ravert HT, Dipaola AF Jr, Wagner HN Jr. J Nucl Biol Med 1994;38:521-526. [PubMed: 7865551]

18. Madar I, Anderson JH, Szabo Z, Scheffel U, Kao PF, Ravert HT, Dannals RF. J Nucl Med 1999;40:1180-1185. [PubMed: 10405140]

19. Madar I, Weiss L, Izbicki G. J Nucl Med 2002;43:234-238. [PubMed: 11850490]

20. Ravert HT, Madar I, Dannals RF. J Label Compd Radiopharm 2004;47:469-476.

21. Madar I, Ravert HT, Du Y, Hilton J, Volokh L, Dannals RF, Frost JJ, Hare JM. J Nucl Med 2006;47:1359-1366. [PubMed: 16883017]

22. Cheng Z, Subbarayan M, Chen X, Gambhir SS. J Label Compd Radiopharm 2005;48:131-137.

23. Min JJ, Biswal S, Deroose C, Gambhir SS. J Nucl Med 2004;45:636-643. [PubMed: 15073261]

24. Steichen JD, Weiss MJ, Elmaleh DR, Martuza RL. J Neurosurg 1991;74:116-122. [PubMed: 1984490]

25. Cheng Z, Winant RC, Gambhir SS. J Nucl Med 2005;46:878-886. [PubMed: 15872363]

26. Wang J, Yang C-T, Kim Y-S, Sreerama SG, Chen X, Liu S. Submitted

27. Kim Y-S, Yang C-T, Wang J, Sreerama SG, Chen X, He Z, Liu S. Manuscript in preparation

28. Otwinowski Z, Minor W. Methods Enzymol 1997;276:307.

29. Oszlanyi G, Suto A. Acta Cryst 2004;A60:134.

30. Spek, AL. PLATON, Molecular Graphics Program. University of Ultrecht; The Netherlands: 1991.

31. Burla MC, Caliandro R, Camalli M, Carrozzini B, Cascarano GL, Caro LDe, Giacovazzo C, Polidori G, Spagna R. J Appl Cryst 2005;38:381.

32. Sheldrick, GM. SHELXL 97. A Program for Crystal Structure Refinement. University of Göttingen; Göttingen, Germany: 1997.

33. Johnson, CK. ORTEPII, Report ORNL-5138. Oak Ridge National Laboratory; Tennessee, USA: 1976.

34. Liu S, Rettig SJ, Orvig C. Inorg Chem 1992;26:5400.

35. Riesen A, Kaden TA, Ritter W, Mäcke HR. Chem Commun 1989:460.

36. Liu S, He Z, Hsieh WY, Fanwick PE. Inorg Chem 2003;42:8831. [PubMed: 14686864]

Inorg Chem. Author manuscript; available in PMC 2008 October 15. 
37. Heppler A, Froidevaux S, Mäcke HR, Jermann E, Béhé M, Powell P, Hennig M. Chem Eur J 1999;5:1974.

38. Viola NA, Rarig RS Jr, Ouellette W, Doyle RP. Polyhedron 2006;25:3457.

39. Wong E, Liu S, Lügger T, Hahn FE, Orvig C. Inorg Chem 1995;34:93.

40. Luo Y, Zhang J, Lu L, Qian M, Wang X, Yang X. Transition Met Chem 2002;27:469.

41. Liao ZR, Zheng XF, Luo BS, Shen LR, Li DF, Liu HL, Zhao W. Polyhedron 2001;20:2813.

42. Viossat V, Lemoine P, Dayan E, Dung NH, Voissat B. Polyhedron 2003;22:1461.

43. Oki AR, Gogineni P, Yurchenko M, Young VG Jr. Inorg Chim Acta 1997;257:279.

44. Baldeau SM, Slinn CH, Krebs B, Rompel A. Inorg Chim Acta 2004;357:3295.

45. Platas-Iglesias C, Vaiana L, Esteban-Gómez David, Avecilla F, Real JA, Blas Ade, Rodríguez-Blas T. Inorg Chem 2005;44:9704. [PubMed: 16363839]

46. Ghachtouli SE, Mohamadou A, Barbier JP. Inorg Chim Acta 2005;358:3873.

47. Coronado E, Galán-Mascarós JR, Martí-Gastaldo C, Martínez AM. Dalton Trans 2006:3294. [PubMed: 16820840]

48. Shannon RD. Acta Crystallogra, Sect A 1976;32:751. 


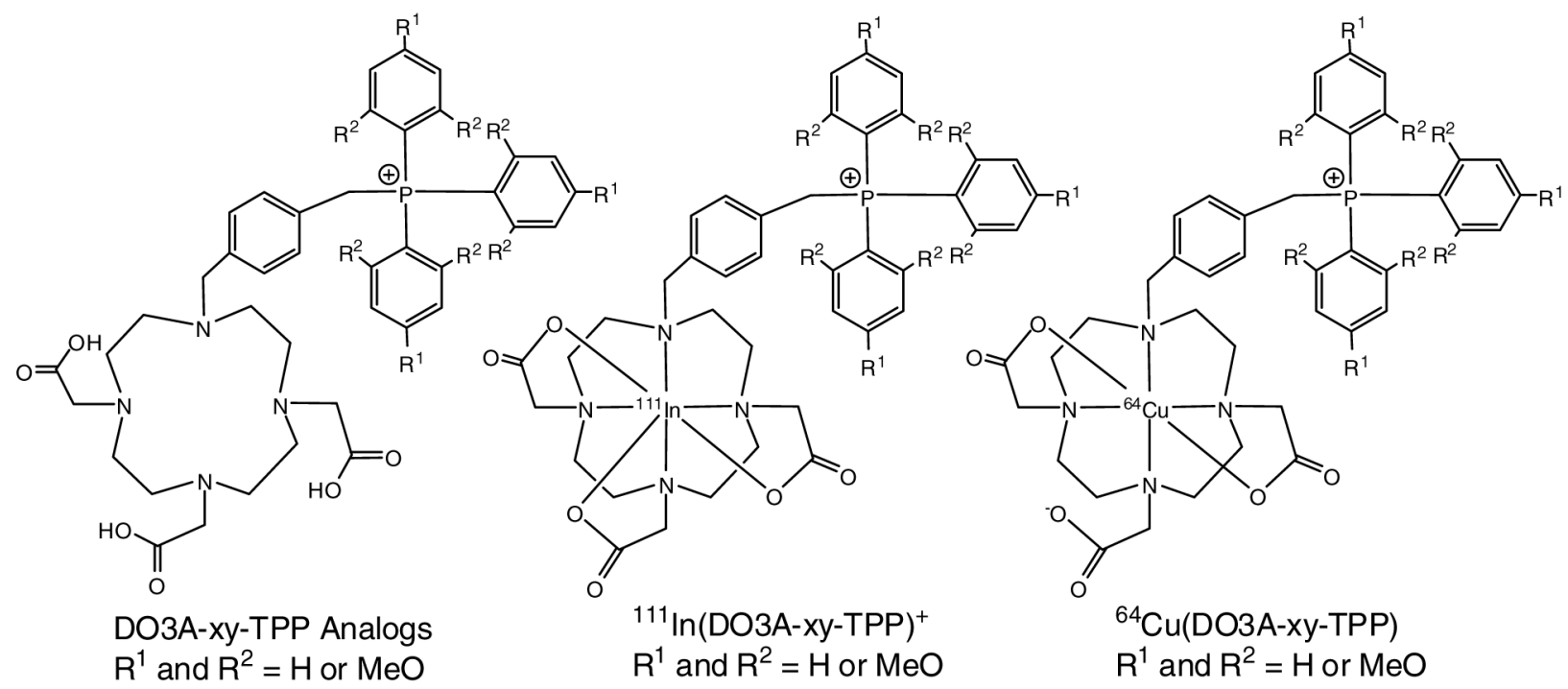

Figure 1.

The DO3A-conjugated TPP analogs and their radiometal complexes useful for imaging tumors. 

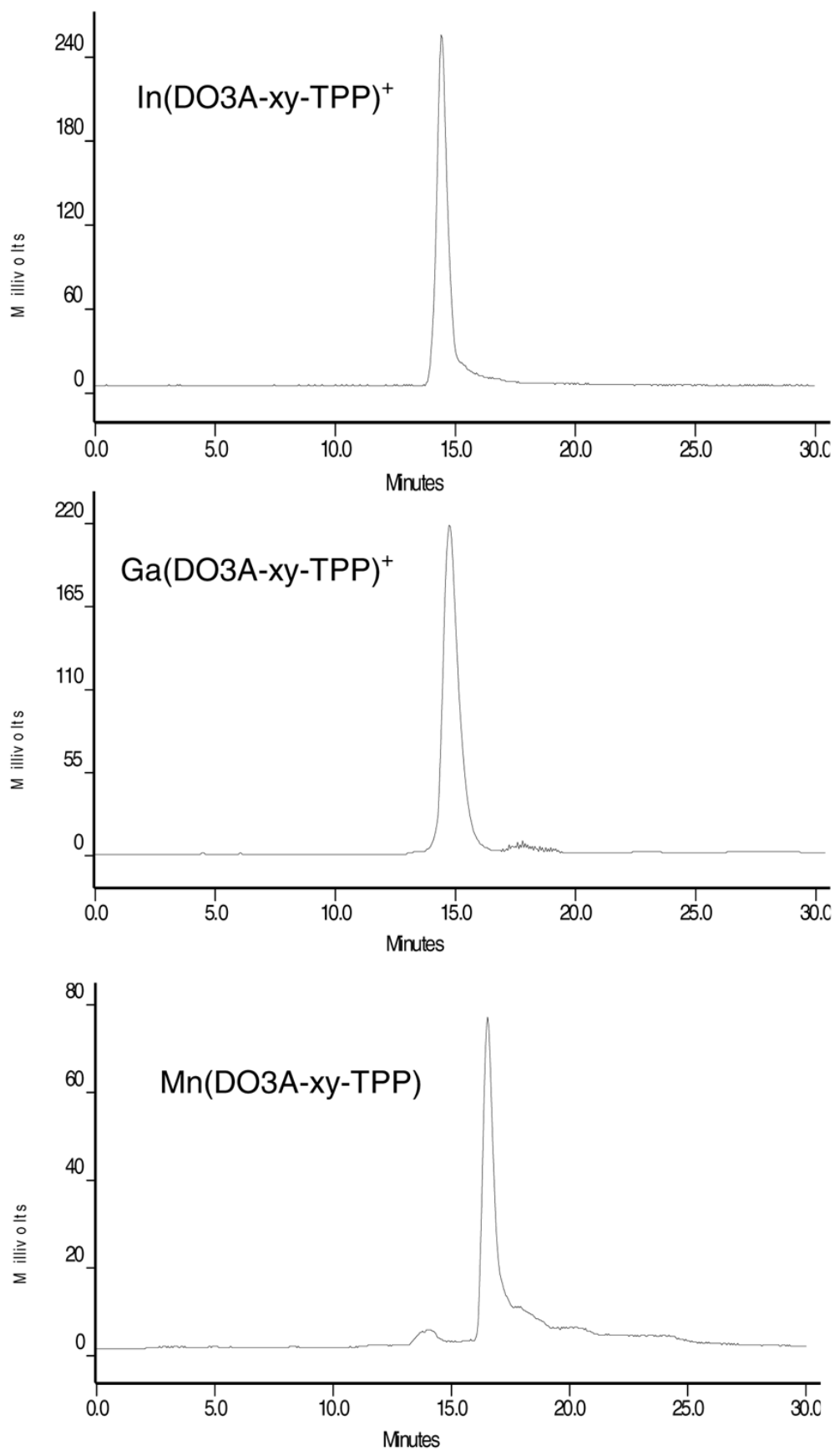

Figure 2.

Representative HPLC chromatograms of Ga(DO3A-xy-TPP $)^{+}$, In(DO3A-xy-TPP $)^{+}$and Mn (DO3A-xy-TPP). 

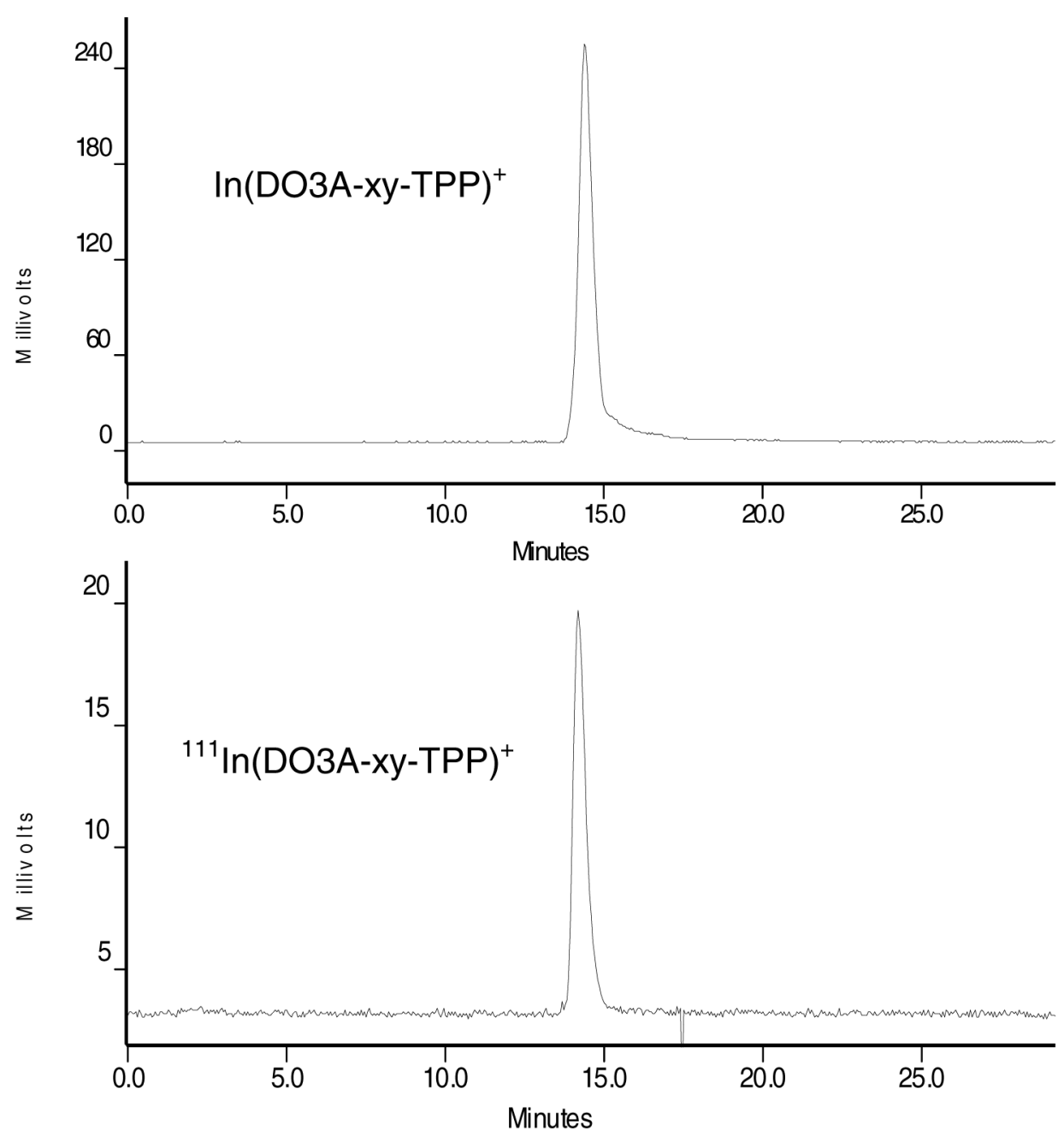

Figure 3.

HPLC concordance for In(DO3A-xy-TPP) ${ }^{+}$(top) and ${ }^{111} \operatorname{In}(\mathrm{DO} 3 \mathrm{~A}-\mathrm{xy}-\mathrm{TPP})^{+}$(bottom). Their identical HPLC retention times suggest that ${ }^{111} \operatorname{In}(\mathrm{DO} 3 \mathrm{~A}-\mathrm{xy}-\mathrm{TPP})^{+}$and $\operatorname{In}(\mathrm{DO} 3 \mathrm{~A}-\mathrm{xy}-\mathrm{TPP})^{+}$ have the same composition. 


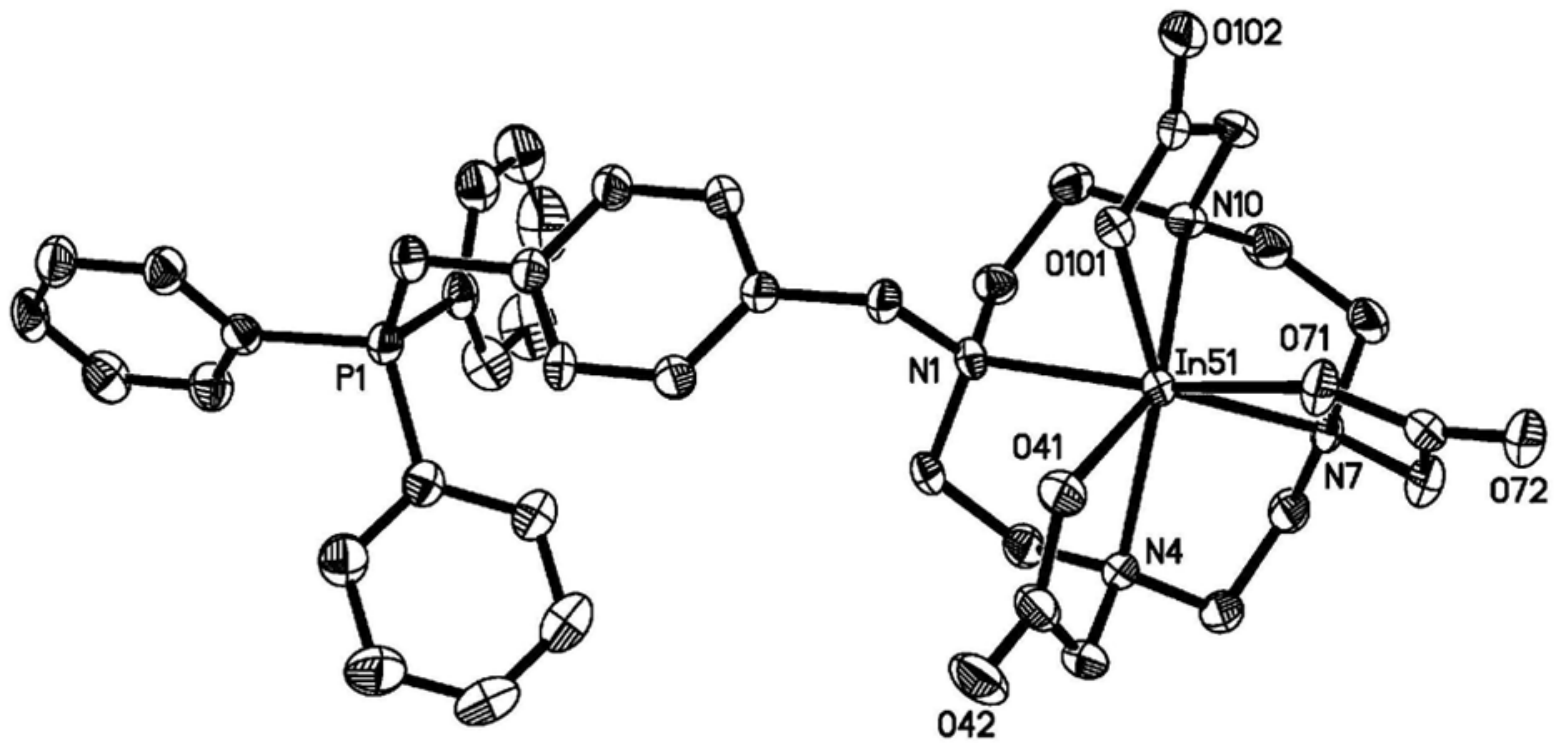

Figure 4.

ORTEP drawing of In(DO3A-xy-TPP) ${ }^{+}$(Ellipoids are at $50 \%$ probability). Crystallization molecules and hydrogen atoms are omitted for the sake of clarity. 


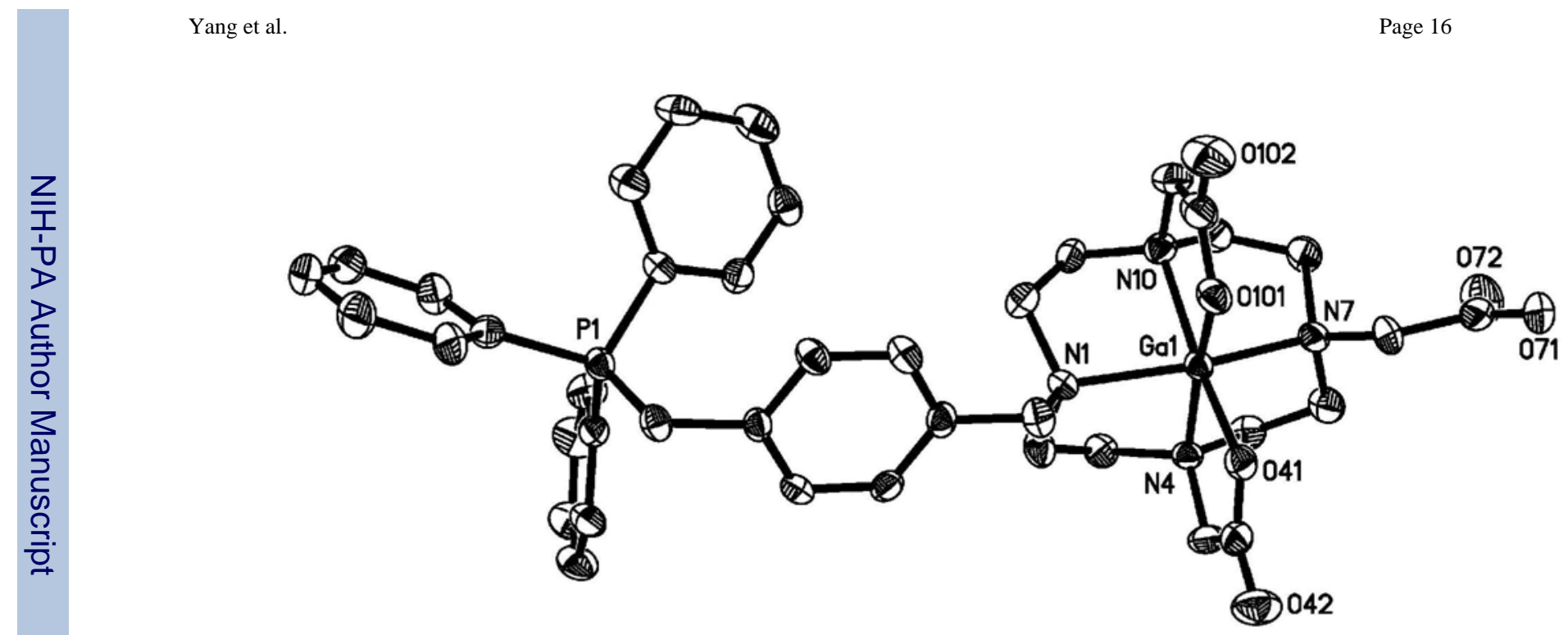

Figure 5.

ORTEP drawing of $\mathrm{Ga}(\mathrm{DO} 3 \mathrm{~A}-\mathrm{xy}-\mathrm{TPP})^{+}$(Ellipoids are at $50 \%$ probability). Crystallization molecules and hydrogen atoms are omitted for the sake of clarity. 


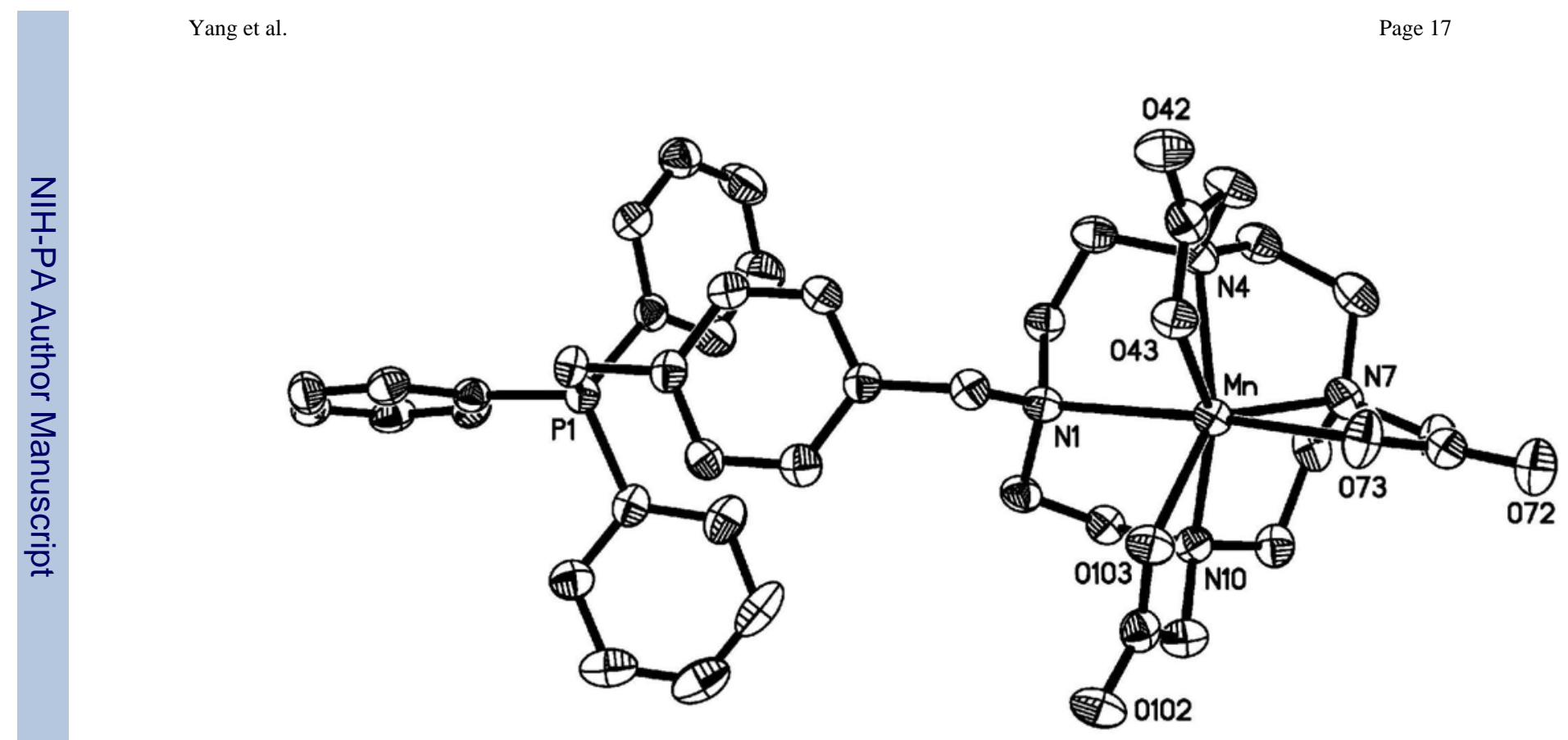

Figure 6.

ORTEP drawing of Mn(DO3A-xy-TPP) (Ellipoids are at 50\% probability). Crystallization water molecules and hydrogen atoms are omitted for the sake of clarity. 


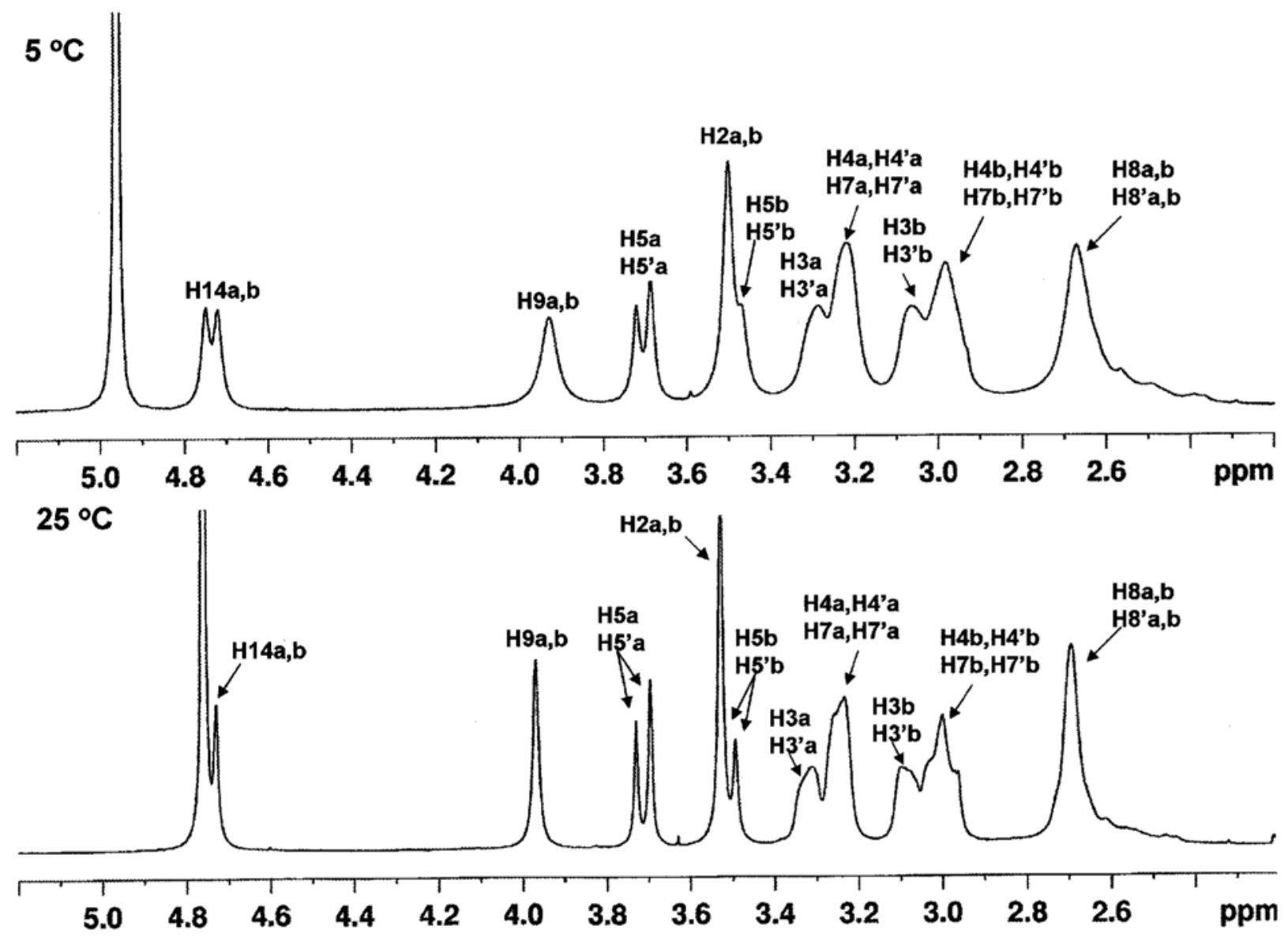

Figure 7.

Aliphatic region of the ${ }^{1} \mathrm{H}$ NMR spectra of $\mathrm{In}(\mathrm{DOTA}-\mathrm{xy}-\mathrm{TPP})^{+}$in $\mathrm{D}_{2} \mathrm{O}$ at $5{ }^{\circ} \mathrm{C}$ (top) and $25^{\circ}$ C (bottom). 

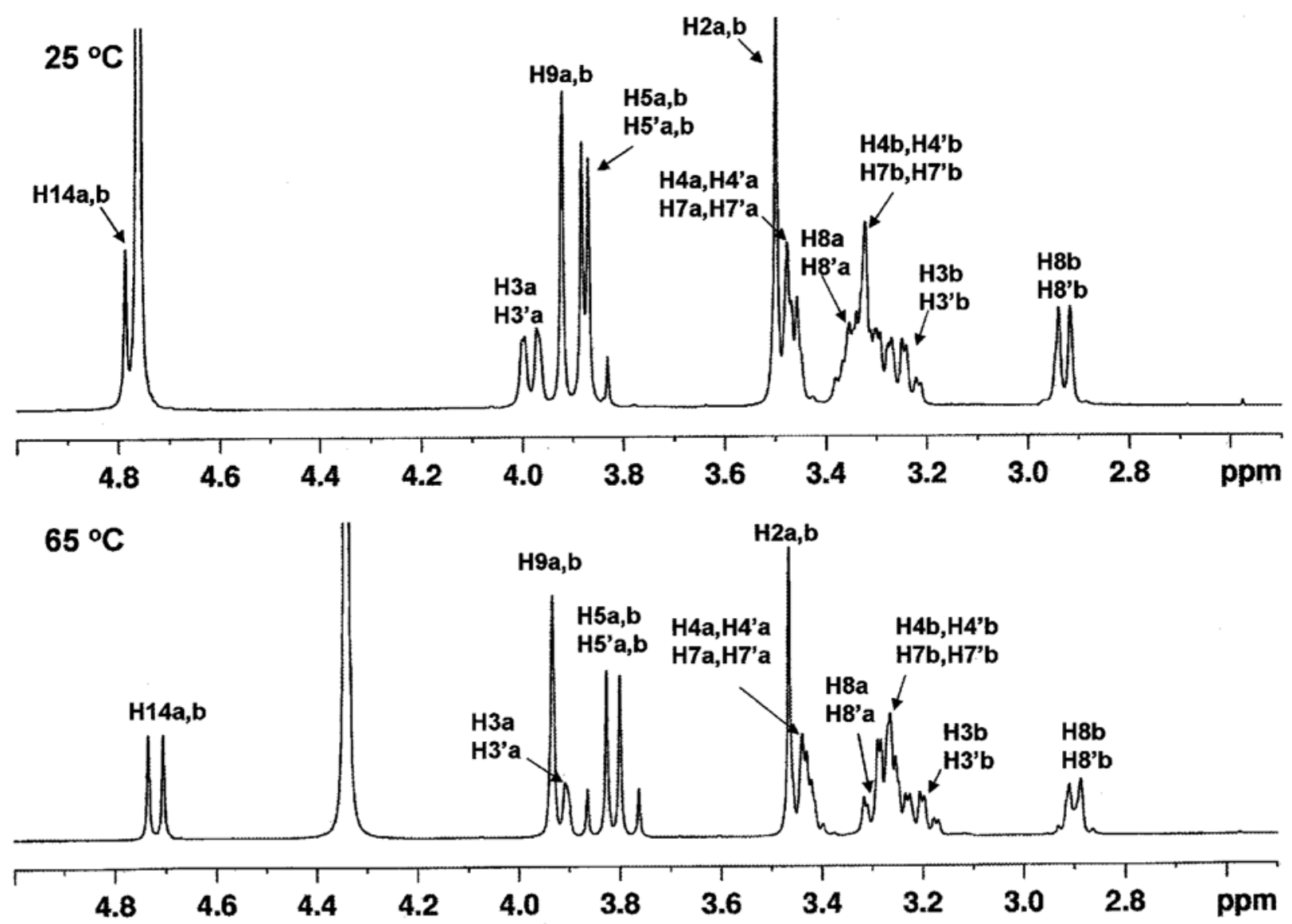

Figure 8.

Aliphatic region of the ${ }^{1} \mathrm{H}$ NMR spectra of $\mathrm{Ga}\left(\right.$ DOTA-xy-TPP) ${ }^{+}$in $\mathrm{D}_{2} \mathrm{O}$ at $25^{\circ} \mathrm{C}$ (top) and 65 ${ }^{\circ} \mathrm{C}$ (bottom). 
Table 1

${ }^{1} \mathrm{H}$ and ${ }^{13} \mathrm{C}$ NMR Data $(500 \mathrm{~Hz})$ for In(DO3A-xy-TPP) ${ }^{+}$and $\mathrm{Ga}(\mathrm{DO} 3 \mathrm{~A}-\mathrm{xy}-\mathrm{TPP}){ }^{+}$. Both ${ }^{1} \mathrm{H}$ and ${ }^{13} \mathrm{C}$ NMR spectra were recorded in $\mathrm{D}_{2} \mathrm{O}$ at $25^{\circ} \mathrm{C}$.

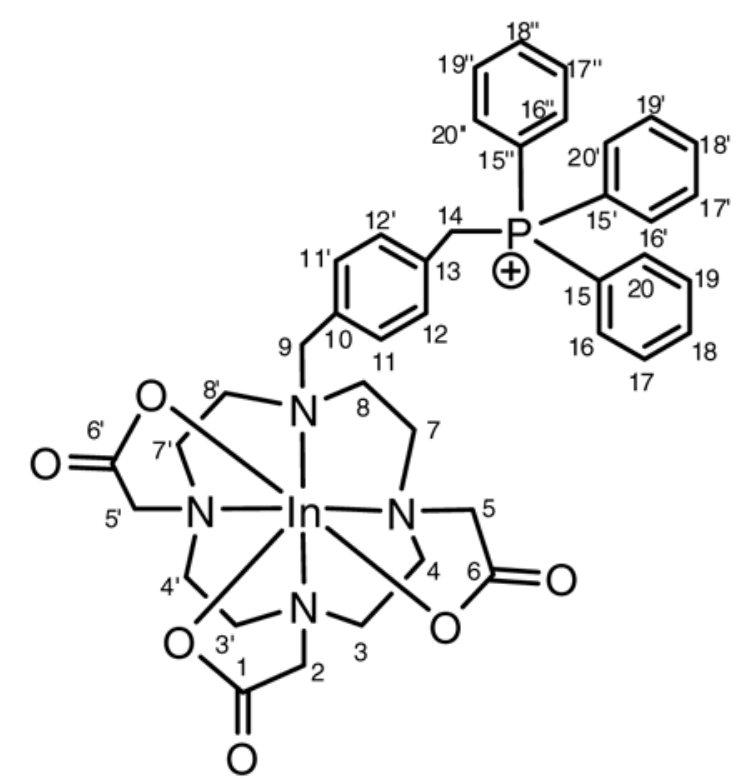

$\ln (\text { DO3A-xy-TPP })^{+}$

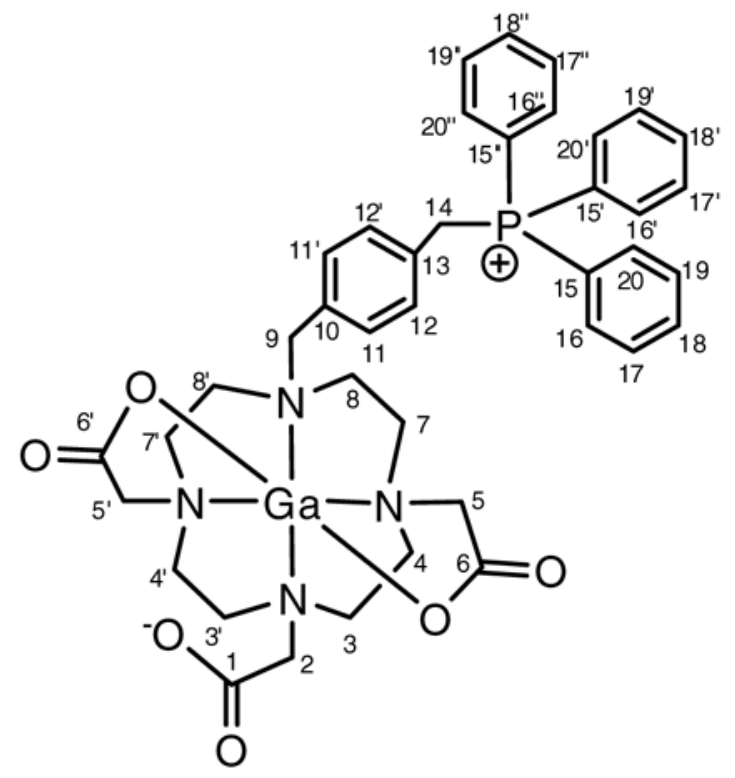

$\mathrm{Ga(DO3A-xy-TPP})^{+}$

\begin{tabular}{|c|c|c|c|c|}
\hline \multirow[b]{2}{*}{ position } & \multicolumn{2}{|c|}{$\operatorname{In}\left(\right.$ DO3A-xy-TPP) ${ }^{+}$} & \multicolumn{2}{|c|}{${\mathrm{Ga}(\mathrm{DO3A}-x y-\mathrm{TPP})^{+}}^{+}$} \\
\hline & $\delta_{H}\left(\right.$ mult., $\left.J_{H H}\right)$ & $\boldsymbol{\delta}_{\mathrm{C}}$ & $\delta_{H}\left(\right.$ mult., $\left.J_{H H}\right)$ & $\boldsymbol{\delta}_{\mathrm{C}}$ \\
\hline 1 & & 178.2 & & 173.1 \\
\hline 2 & $3.53(\mathrm{~s})$ & 60.1 & $3.54(\mathrm{~s})$ & 62.5 \\
\hline $3,3^{\prime}$ & $3.09(\mathrm{~m}), 3.33(\mathrm{~m})$ & 54.8 & $3.26(\mathrm{~m}), 4.02(\mathrm{~m})$ & 53.8 \\
\hline $4,4^{\prime}$ & $3.04(\mathrm{~m}), 3.25(\mathrm{~m})$ & 54.8 & $3.35(\mathrm{~m}), 3.51(\mathrm{~m})$ & 56.2 \\
\hline $5,5^{\prime}$ & 3.62 (AB quartet) & 61.5 & 3.85 (AB quartet) & 58.7 \\
\hline $6,6^{\prime}$ & & 177.9 & & 173.0 \\
\hline $7,7^{\prime}$ & $3.04(\mathrm{~m}), 3.29(\mathrm{~m})$ & 53.5 & $3.35(\mathrm{~m}), 3.51(\mathrm{~m})$ & 56.5 \\
\hline $8,8^{\prime}$ & $2.69(\mathrm{~m})$ & 49.1 & $2.89(\mathrm{~m}), 3.39(\mathrm{~m})$ & 53.3 \\
\hline 9 & $3.96(\mathrm{~s})$ & 58.9 & $3.92(\mathrm{~s})$ & 63.5 \\
\hline 10 & & 132.6 & & 129.9 \\
\hline $11,11^{\prime}$ & $7.11(\mathrm{~d}, 9.8 \mathrm{~Hz})$ & 134.9 & $7.20(\mathrm{~d}, 9.8 \mathrm{~Hz})$ & 131.2 \\
\hline $12,12^{\prime}$ & $7.00(\mathrm{~d}, 9.8 \mathrm{~Hz})$ & 133.7 & $6.96(\mathrm{~d}, 9.8 \mathrm{~Hz})$ & 130.5 \\
\hline 13 & & 131.0 & & 128.2 \\
\hline 14 & $4.78(\mathrm{~d}, 9.8 \mathrm{~Hz})$ & $31.7(d)$ & $4.78(\mathrm{~d}, 9.8 \mathrm{~Hz})$ & $28.6(\mathrm{~d})$ \\
\hline $15,15^{\prime}, 15^{\prime \prime}$ & & $119.7(d)$ & & 116.3 \\
\hline $16,16^{\prime}, 16^{\prime \prime}$ & $7.65(\mathrm{~m})$ & 136.6 & $7.57(\mathrm{~m})$ & 133.3 \\
\hline $17,17^{\prime}, 17^{\prime \prime}$ & $7.65(\mathrm{~m})$ & 132.5 & $7.57(\mathrm{~m})$ & 129.1 \\
\hline $18,18^{\prime}, 18^{\prime \prime}$ & $7.86(\mathrm{t})$ & 137.7 & $7.78(\mathrm{~m})$ & 134.4 \\
\hline $19,19^{\prime}, 19^{\prime \prime}$ & $7.65(\mathrm{~m})$ & 132.5 & $7.57(\mathrm{~m})$ & 129.1 \\
\hline $20,20^{\prime}, 20^{\prime \prime}$ & $7.65(\mathrm{~m})$ & 136.6 & $7.57(\mathrm{~m})$ & 133.3 \\
\hline
\end{tabular}


Table 2

Selected crystallographic data and structure refinements details for $\mathrm{In}(\mathrm{DO} 3 \mathrm{~A}-\mathrm{xy}-\mathrm{TPP})(\mathrm{OAc}) \cdot 7.5 \mathrm{H}_{2} \mathrm{O} \cdot\left(\mathrm{CH}_{3}\right)_{2} \mathrm{CO}$, Ga (DO3A-xy-TPP) $\left(\mathrm{NO}_{3}\right) \cdot 6 \mathrm{H}_{2} \mathrm{O} \cdot\left(\mathrm{CH}_{3}\right)_{2} \mathrm{CO}$ and $\mathrm{Mn}(\mathrm{DO} 3 \mathrm{~A}-\mathrm{xy}-\mathrm{TPP}) \cdot 4 \mathrm{H}_{2} \mathrm{O} \cdot \mathrm{CH}_{3} \mathrm{OH}$.

\begin{tabular}{|c|c|c|c|}
\hline formula & $\mathrm{C}_{45} \mathrm{H}_{69} \mathrm{InN}_{4} \mathrm{O}_{16.5} \mathrm{P}$ & $\mathrm{C}_{43} \mathrm{H}_{64} \mathrm{GaN}_{5} \mathrm{O}_{16} \mathrm{P}$ & $\mathrm{C}_{41} \mathrm{H}_{57} \mathrm{MnN}_{4} \mathrm{O}_{11} \mathrm{P}$ \\
\hline $\begin{array}{l}\text { fw } \\
\text { space group } \\
\lambda,(\AA) \\
\mathrm{a}, \AA \\
\mathrm{b}, \AA \\
\mathrm{c}, \AA \\
\alpha, \mathrm{deg} \\
\beta, \mathrm{deg} \\
\gamma, \mathrm{deg} \\
\mathrm{V}, \AA^{3} \\
\mathrm{Z} \\
\mathrm{d}_{\mathrm{calc}}, \mathrm{g} / \mathrm{cm}^{3} \\
\mathrm{~T},(\mathrm{~K}) \\
\mu, \mathrm{mm}^{-1} \\
\operatorname{transmission~coeff~}^{-1} \\
\mathrm{R}\left(\mathrm{F}_{\mathrm{o}}\right) \\
\mathrm{R}_{\mathrm{w}}\left(\mathrm{F}_{\mathrm{o}}{ }^{2}\right)\end{array}$ & $\begin{array}{l}1075.83 \\
\mathrm{P} \text { I (No. 2) } \\
\operatorname{Mo~K}_{\alpha}(0.71073) \\
10.7779(9) \\
16.3040(17) \\
16.4520(18) \\
103.482(6) \\
106.939(6) \\
104.783(6) \\
2522.0(4) \\
2 \\
1.417 \\
150 \\
0.572 \\
0.788,0.932 \\
0.056^{a} \\
0.135^{b}\end{array}$ & $\begin{array}{l}1007.71 \\
\operatorname{Pca}_{1} \text { (No. 29) } \\
\operatorname{Mo~K}_{\mathrm{a}}(0.71073) \\
28.9585(9) \\
8.15090(10) \\
19.6548(6) \\
90 \\
90 \\
90 \\
4639.3(2) \\
4 \\
1.443 \\
150 \\
0.696 \\
0.812,0.773 \\
0.043 a \\
0.094 b\end{array}$ & $\begin{array}{l}867.84 \\
\mathrm{P} 2 / \mathrm{c}(\mathrm{No} .14) \\
\mathrm{Mo} \mathrm{K}_{\mathrm{a}}(0.71073) \\
12.8899(9) \\
19.1761(10) \\
17.1960(13) \\
90 \\
103.84(4) \\
90 \\
4127.0(5) \\
4 \\
1.397 \\
150 \\
0.406 \\
0.954,0.985 \\
0.069 a \\
0.161^{b}\end{array}$ \\
\hline
\end{tabular}

$a_{\mathrm{R}}=\Sigma \| \mathrm{F}_{\mathrm{O}}|-| \mathrm{F}_{\mathrm{C}}|/ \Sigma| \mathrm{F}_{\mathrm{O}} \mid$ for $\mathrm{F}_{\mathrm{O}}^{2}>2 \sigma\left(\mathrm{F}_{\mathrm{O}}{ }^{2}\right)$.

$b_{\mathrm{R}_{\mathrm{W}}}=\left[\Sigma \mathrm{w}\left(\left|\mathrm{F}_{\mathrm{O}}^{2}\right|-\left|\mathrm{F}_{\mathrm{C}}{ }^{2}\right|\right)^{2} / \Sigma \mathrm{w}\left|\mathrm{F}_{\mathrm{O}}^{2}\right|^{2}\right]^{1 / 2}$ 
Table 3

Selected bond distances $(\AA)$ and bond angles $\left(^{\circ}\right)$ in $\mathrm{In}(\mathrm{DO} 3 \mathrm{~A}-\mathrm{xy}-\mathrm{TPP})(\mathrm{OAc}) \cdot 7.5 \mathrm{H}_{2} \mathrm{O} \cdot\left(\mathrm{CH}_{3}\right)_{2} \mathrm{CO}$.

\begin{tabular}{|c|c|c|c|}
\hline Atom 1 & Atom 2 & Distance & \\
\hline In51 & O41 & $2.159(3)$ & \\
\hline In51 & O71 & $2.162(3)$ & \\
\hline In51 & O101 & $2.202(3)$ & \\
\hline In51 & N10 & $2.327(3)$ & \\
\hline In51 & N1 & $2.375(3)$ & \\
\hline In51 & N7 & $2.395(3)$ & \\
\hline In51 & $\mathrm{N} 4$ & 2.399(3) & \\
\hline Atom 1 & Atom 2 & Atom 3 & Angle \\
\hline O41 & In51 & O71 & $87.22(14)$ \\
\hline $\mathrm{O} 41$ & In51 & O101 & $84.51(12)$ \\
\hline O71 & In51 & O101 & $79.45(13)$ \\
\hline $\mathrm{O} 41$ & In51 & N10 & $152.56(14)$ \\
\hline O71 & In51 & N10 & $103.51(14)$ \\
\hline O101 & In51 & N10 & 73.04(13) \\
\hline $\mathrm{O} 41$ & In51 & N1 & $86.06(13)$ \\
\hline O71 & In51 & N1 & $164.99(14)$ \\
\hline O101 & In51 & N1 & $86.55(13)$ \\
\hline N10 & In51 & N1 & $77.22(14)$ \\
\hline $\mathrm{O} 41$ & In51 & N7 & $131.71(14)$ \\
\hline O71 & In51 & N7 & 73.31(15) \\
\hline O101 & In51 & N7 & $131.84(13)$ \\
\hline N10 & In51 & N7 & 75.72(14) \\
\hline N1 & In51 & N7 & $120.82(14)$ \\
\hline $\mathrm{O} 41$ & In51 & N4 & 75.61(14) \\
\hline O71 & In51 & N4 & $114.19(13)$ \\
\hline O101 & In51 & N4 & $154.85(14)$ \\
\hline N10 & In51 & N4 & $120.38(14)$ \\
\hline N1 & In51 & N4 & 77.00(13) \\
\hline N7 & In51 & N4 & $73.30(14)$ \\
\hline
\end{tabular}


Table 4

Selected bond distances $(\AA)$ and bond angles $\left(^{\circ}\right)$ in $\mathrm{Ga}(\mathrm{DO} 3 \mathrm{~A}-\mathrm{xy}-\mathrm{TPP})\left(\mathrm{NO}_{3}\right) \cdot 6 \mathrm{H}_{2} \mathrm{O} \cdot\left(\mathrm{CH}_{3}\right)_{2} \mathrm{CO}$.

\begin{tabular}{|c|c|c|c|}
\hline Atom 1 & Atom 2 & Distance & \\
\hline Ga1 & $\mathrm{O} 41$ & $1.926(2)$ & \\
\hline $\mathrm{Ga} 1$ & O101 & $1.934(3)$ & \\
\hline $\mathrm{Ga} 1$ & N4 & $2.115(3)$ & \\
\hline $\mathrm{Ga} 1$ & N10 & $2.122(3)$ & \\
\hline $\mathrm{Ga} 1$ & N7 & $2.125(3)$ & \\
\hline $\mathrm{Ga} 1$ & N1 & $2.147(2)$ & \\
\hline Atom 1 & Atom 2 & Atom 3 & Angle \\
\hline O41 & $\mathrm{Ga} 1$ & O101 & $84.95(12)$ \\
\hline O41 & Ga1 & N4 & $84.17(11)$ \\
\hline O101 & Ga1 & N4 & $168.95(11)$ \\
\hline O41 & Ga1 & N10 & $168.13(11)$ \\
\hline O101 & Ga1 & N10 & $83.25(12)$ \\
\hline $\mathrm{N} 4$ & Ga1 & N10 & 107.67(11) \\
\hline O41 & $\mathrm{Ga} 1$ & N7 & $97.49(10)$ \\
\hline O101 & Ga1 & N7 & $99.82(11)$ \\
\hline $\mathrm{N} 4$ & Ga1 & N7 & $83.52(12)$ \\
\hline N10 & Ga1 & N7 & $83.35(11)$ \\
\hline $\mathrm{O} 41$ & $\mathrm{Ga} 1$ & N1 & $99.95(9)$ \\
\hline O101 & Ga1 & N1 & $96.91(12)$ \\
\hline $\mathrm{N} 4$ & $\mathrm{Ga} 1$ & N1 & $83.10(12)$ \\
\hline N10 & $\mathrm{Ga} 1$ & N1 & $82.72(11)$ \\
\hline N7 & $\mathrm{Ga} 1$ & N1 & $156.76(11)$ \\
\hline
\end{tabular}


Table 5

Selected bond distances $(\AA)$ and bond angles $\left({ }^{\circ}\right)$ in $\mathrm{Mn}(\mathrm{DO} 3 \mathrm{~A}-\mathrm{xy}-\mathrm{TPP}) \cdot 4 \mathrm{H}_{2} \mathrm{O} \cdot \mathrm{CH}_{3} \mathrm{OH}$.

\begin{tabular}{|c|c|c|c|}
\hline Atom 1 & Atom 2 & Distance & \\
\hline $\mathrm{Mn}$ & O103 & $2.161(3)$ & \\
\hline $\mathrm{Mn}$ & $\mathrm{O} 73$ & $2.190(3)$ & \\
\hline $\mathrm{Mn}$ & $\mathrm{O} 43$ & $2.196(3)$ & \\
\hline $\mathrm{Mn}$ & $\mathrm{N} 4$ & $2.379(3)$ & \\
\hline $\mathrm{Mn}$ & N10 & $2.421(3)$ & \\
\hline $\mathrm{Mn}$ & N1 & $2.447(3)$ & \\
\hline $\mathrm{Mn}$ & N7 & $2.455(3)$ & \\
\hline Atom 1 & Atom 2 & Atom 3 & Angle \\
\hline O103 & $\mathrm{Mn}$ & $\mathrm{O} 73$ & $89.64(11)$ \\
\hline $\mathrm{O} 103$ & $\mathrm{Mn}$ & $\mathrm{O} 43$ & $87.98(10)$ \\
\hline $\mathrm{O} 73$ & $\mathrm{Mn}$ & $\mathrm{O} 43$ & $84.66(11)$ \\
\hline $\mathrm{O} 103$ & $\mathrm{Mn}$ & $\mathrm{N} 4$ & $150.19(11)$ \\
\hline $\mathrm{O} 73$ & $\mathrm{Mn}$ & N4 & $110.85(12)$ \\
\hline $\mathrm{O} 43$ & $\mathrm{Mn}$ & $\mathrm{N} 4$ & $73.29(11)$ \\
\hline O103 & $\mathrm{Mn}$ & N10 & $74.55(11)$ \\
\hline $\mathrm{O} 73$ & $\mathrm{Mn}$ & N10 & $107.81(12)$ \\
\hline $\mathrm{O} 43$ & $\mathrm{Mn}$ & N10 & $158.14(11)$ \\
\hline N4 & $\mathrm{Mn}$ & N10 & $116.45(12)$ \\
\hline $\mathrm{O} 103$ & $\mathrm{Mn}$ & N1 & $82.34(11)$ \\
\hline $\mathrm{O} 73$ & $\mathrm{Mn}$ & N1 & $170.65(11)$ \\
\hline $\mathrm{O} 43$ & $\mathrm{Mn}$ & N1 & $90.23(11)$ \\
\hline N4 & $\mathrm{Mn}$ & N1 & 74.94(11) \\
\hline N10 & $\mathrm{Mn}$ & N1 & $74.75(11)$ \\
\hline $\mathrm{O} 103$ & $\mathrm{Mn}$ & N7 & $134.40(11)$ \\
\hline $\mathrm{O} 73$ & $\mathrm{Mn}$ & N7 & $71.13(11)$ \\
\hline $\mathrm{O} 43$ & $\mathrm{Mn}$ & N7 & $128.75(11)$ \\
\hline N4 & $\mathrm{Mn}$ & N7 & 74.43(11) \\
\hline N10 & $\mathrm{Mn}$ & N7 & $72.98(11)$ \\
\hline
\end{tabular}

